\title{
Financial Literacy: A Barrier to Home Ownership for the Young?
}

\author{
John Gathergood* \\ University of Nottingham, School of Economics \\ Network for Integrated Behavioural Science \\ Jörg Weber ${ }^{\dagger}$ \\ University of Nottingham, School of Economics \\ Centre for Decision Research and Experimental Economics \\ Network for Integrated Behavioural Science
}

Accepted Version February 2017

\begin{abstract}
The decision to buy a home is one of the most important choices faced by a household. Most young households who purchase a home do so using a mortgage. But mortgages are complex financial instruments and this complexity may be a barrier to less sophisticated households becoming homeowners. Using survey data from a sample of English and Welsh households we measure household financial literacy related to mortgages, including concepts such as loan duration, interest compounding and amortization. We find that in the population mortgage financial literacy is generally low and among renters mortgage financial literacy is substantially worse than among homeowners. Econometric estimates show mortgage financial literacy predicts home ownership for younger, but not for older households. Financial literacy also affects the type of mortgage and leverage position of younger households. Young homeowners with poorer financial literacy take on larger mortgage debts and are more likely to use alternative mortgage products.
\end{abstract}

Keywords: home ownership, financial literacy, mortgages, household finance

JEL Codes: D10, D12, G21

\footnotetext{
* Corresponding author. Email address: john.gathergood@nottingham.ac.uk.

$\dagger$ Email address: joerg.weber@nottingham.ac.uk.

We would like to thank the editor and two anonymous referees for their extensive comments on earlier versions of paper. We acknowledge research funding that contributed towards this work under ESRC grants RES-06125-0478 and ES/K002201/1 (Network for Integrated Behavioural Science). We would also like to thank YouGov for incorporating questions into their household survey and making the data available for the purposes of this research project.
} 


\section{Introduction}

The decision to buy a family home is one of the most important financial choices made by households. The family home is typically the largest single durable good purchased over the life-cycle, for which financial and non-financial costs of adjustment can be large. It is also an investment asset, a source of collateral and in many cases the main component of a bequest. A large literature has considered the benefits arising from home ownership (DiPasquale and Glaeser, 1999; Engelhardt et al., 2010; Grinstein-Weiss et al., 2013; Coulson and $\mathrm{Li}, 2013$ ), including local amenities and social capital effects plus also positive effects on child well-being (Haurin et al., 2002) and consumption smoothing (Benito and Mumtaz, 2009). For a review of the effects of home ownership see Dietz and Haurin (2003).

Given the importance of home ownership, understanding the barriers to achieving ownership faced by younger households is an important research topic. Younger households may choose not to own their homes due to their higher rates of geographic mobility coupled with transaction costs of moving across owner-occupied housing. Nevertheless, prior studies have identified a broad range of potential barriers including borrowing constraints (Haurin et al., 1997; Ortalo-Magné and Sven, 2006; Chambers et al., 2009; Kolodziejczyk and LethPetersen, 2013), lack of mortgage market development (Sanders, 2005) and racial differences (Charles and Hurst, 2002; Collins and Margo, 2011). A large literature also considers the interplay between house price volatility, rental price volatility and income risk (Sinai and Souleles, 2005; Banks et al., 2016; Amior and Halket, 2014; Bostic and Lee, 2008; DiazSerrano, 2005). Many government initiatives have been introduced to alleviate barriers to home ownership including, for example, mortgage subsidies (Fetter, 2013; Glaeser and Shapiro, 2003) and discounted private sales of social housing (Aalbers, 2004), though the long-term effects of these appear limited (Gabriel and Rosenthal, 2015). However, there is some evidence that pre-purchase financial counseling reduces delinquency (Hirad et al., 2001).

Is poor financial literacy also a barrier to home ownership? For most young households, an integral component of purchasing a home is a mortgage. But a mortgage is a complex financial product requiring a degree of financial sophistication on the part of households (Campbell, 2006; Bucks and Pence, 2008; Agarwal et al., 2013). Lack of financial understanding of mortgage products may affect younger households in particular, as they may lack financial experience. This might in turn go some way to explaining the age-home ownership gradient. Existing studies show home ownership rates increase sharply with age 
(Haurin and Rosenthal, 2007), partly due to borrowing constraints among the young (Haurin et al., 1997). Lack of financial literacy may be another important constraint for younger households.

In this paper, we use a specially commissioned survey of a representative sample of English and Welsh households to examine whether poor financial literacy is a barrier to home ownership, particularly among the young. We also examine whether, conditional on home ownership, financial literacy affects the type of terms of mortgage products used by younger households. Our study is closest to that of Haurin and Morrow-Jones (2006), who show that home ownership rates increase with real estate market knowledge among a sample of residents in the Columbus, Ohio area. The authors show this contributes to the racial gap in home ownership rates. Whereas Haurin and Morrow-Jones (2006) focus on the racial gap in home ownership, our study focuses on the relationship between financial literacy and the agehome ownership gradient. Recent studies have also shown that poor financial literacy discourages households from participation in a range of financial markets ${ }^{3}$.

We measure the financial literacy of households in the domain of mortgage choice by inserting multiple-choice questions into our survey, encapsulating concepts of loan duration, interest calculation, interest compounding and loan amortization. The multiple-choice questions we include do not require complicated mathematical calculations, but do require an understanding of key economic concepts. Alongside our questions on financial literacy, we include a broad set of questions to capture relevant variables, which explain home ownership choices, including measures of income risk and credit constraints. We also consider other behavioral determinants of home ownership, including the role of risk attitude and time preferences in the form of patience and present bias ${ }^{4}$.

The decision to invest in understanding mortgages is itself potentially secondary to the decision to become a homeowner, or could be learned through mortgage market experience. We therefore follow recent studies in adopting an instrumental variable (IV) strategy in which we instrument the financial literacy index with a source of variation in financial literacy that pre-dates mortgage market experience. Among a range of possible instruments we use

\footnotetext{
${ }^{3}$ For example, lack of understanding of the stock market and investment vehicles lowers the likelihood of households owning stocks (van Rooij et al., 2011b). Also, ignorance of basic financial concepts integral to retirement saving discourages individuals from forming a plan for retirement saving (Lusardi and Mitchell, 2007a). In recent research we show that financial literacy is an important determinant for choice of mortgage type (Gathergood and Weber, 2015).

${ }^{4}$ In our recent paper we show that time preferences are important for choice of mortgage type, specifically the choice over a standard repayment mortgage or an alternative mortgage with interest-only payments (Gathergood and Weber, 2015).
} 
mathematical performance when young, shown to be a powerful instrument in a recent study by Jappelli and Padula (2013). Mathematical performance at school when young pre-dates housing market experience and therefore removes any learning effects through owning a home. However, there may be other unobserved factors pertaining to home ownership that correlate with our instrument, such as parental wealth and bequests. Hence, unobserved factors might still in part explain the relationship we find between financial literacy and home ownership.

Our results show levels of mortgage financial literacy among our sample are generally low. Among our whole sample comprising homeowners and renters, the average number of questions answered correctly is two out of four. Most respondents answer questions on loan duration and a simple interest calculation correctly, but only $40 \%$ show understanding of compound interest and less than one third answer our loan amortization question correctly. However, financial literacy is better among homeowners compared with renters - and this is true for both older and younger households. Households who score highest on the financial literacy index are 20 percentage points more likely to be homeowners compared with the lowest scoring households. In an unconditional comparison, answering one more financial literacy question correctly is associated with a 5 percentage point increase in the likelihood of home ownership.

When we estimate econometric models, we find a clear result that financial literacy raises the likelihood of home ownership among younger households in our sample, but has no statistically significant effect on home ownership among older households. This result is robust to the inclusion of a broad range of controls for demographic, socio-economic and local housing market conditions as well as other behavioral characteristics measured at the individual level. We also test the sensitivity of our results to alternative sample restrictions, with results unchanged. To gauge the quantitative importance of financial literacy, a one-unit increase in financial literacy (that is answering one more of our questions correctly) increases the likelihood of home ownership among young households by $5.3 \%$, an effect equivalent to increasing household permanent income by approximately $£ 5,000$ per year.

As an extension of our analysis of how financial literacy affects home ownership choices, in the second part of the paper we analyze the mortgage choices of young households. Most young households require a mortgage to become homeowners, but households with less understanding of mortgage products may be more exposed to taking on riskier mortgages, especially when young and lacking mortgage market experience. Such households may also be more susceptible to predatory lending practices, which tend to target 
subprime households with lower levels of financial sophistication (Ho and Pennington-Cross, 2006; Bond et al., 2009; Agarwal et al., 2014). For example, alternative mortgage products (AMPs) offer some features such as 'interest only' terms or slower amortization that could be attractive to younger households desiring to buy a home, but may not fully understand mortgage terms and misinterpret the short-term benefits of these products. We estimate a series of models in which we relate financial literacy to mortgages types (standard vs. alternative mortgage; fixed vs. adjustable rate) and mortgage characteristics (loan-to-value ratio and loan-to-income ratio). To econometrically control for selection into holding a mortgage, we use a selectivity correction. The selectivity correction is used together with the IV model to control for the endogeneity of financial literacy.

Results show that young mortgage homeowners with lower financial literacy make mortgage choices that result in holding higher levels of mortgage debt (relative to the value of their home and relative to their income) and use potentially riskier AMPs. These findings are suggestive that poor financial literacy causes households to take more risks in the mortgage market, though they might also reflect unobserved factors such as low wealth, which induce households to take AMPs. We also show that lower financial literacy increases the likelihood of a young household choosing to fix their mortgage interest rate and refinance their mortgage.

The remainder of the paper proceeds as follows. In Section 2 we describe our survey design, content and questions that comprise the financial literacy index. In Section 3 we present descriptive results for the relationship between financial literacy and home ownership. In Section 4 we present estimates from our econometric models, first models that explain home ownership status and second models that explain the characteristics of mortgages held by young households. Section 5 concludes the paper.

\section{Data}

\subsection{Survey Data}

Our main data source is a cross-sectional survey of a representative sample of English and Welsh households into which we add supplementary questions on financial literacy and behavioral characteristics. The survey is conducted by the London-based market research firm YouGov and is known as the 'Debt Tracker' survey. YouGov has access to a panel of 350,000 households and draws a sample of approximately 2,000 households for each 
quarterly wave of the Debt Tracker survey ${ }^{5}$. We use the August 2013 wave. The survey is administered online and achieves a representative sample by making special provision for respondents who do not have access to the internet.

\subsection{Core Variables and Measures of Income Volatility and Credit Constraints}

The survey data includes a broad range of socio-economic variables including demographic, education and labor market variables plus detailed information on the assets and debt of the household ${ }^{6}$. Housing variables include housing tenure (being a homeowner without a mortgage, a homeowner with a mortgage, renter), the value of the main residence and total mortgage debt outstanding on the main residence. There is also some information on the terms of the mortgage, including the interest rate of the current mortgage and when the mortgage was refinanced the last time.

The data also contains measures credit constraints and income volatility. Prior studies have shown that these are important determinants of home ownership (Haurin et al., 1997; Ortalo-Magné and Sven, 2006; Chambers et al., 2009; Kolodziejczyk and Leth-Petersen, 2013). We identify credit constrained households with a set of survey questions from which we create a $1 / 0$ dummy variable to denote credit constraints. This dummy is 1 if respondents answer 'yes' to at least one of four statements that describe whether they or their partner cannot currently get new credit, had a credit line withdrawn, a credit line reduced or whether they have exceeded their credit line. A household is also classified as credit constrained if respondents state that applications to unsecured credit products have been turned down. We also construct a measure of income volatility in the sense of recent income loss. We use four questions to create a create a dummy variable that is 1 if the respondent states that they or their partner have experienced recent reductions in income arising from changes in labor or non-labor income or changes in employment status.

\footnotetext{
5 The YouGov Debt Tracker surveys a representative sample of the UK population, i.e. England, Northern Ireland, Scotland and Wales. Subjects are recruited from the YouGov panel, with the target sample stratified to represent the UK population by age, gender, home ownership and employment status. The survey achieves an $80 \%$ response rate. Respondents are paid $£ 10$ for participation in the survey, which takes approximately 45 minutes to complete. Further details on the survey are provided at https://yougov.co.uk/findsolutions/reports/trackers/debt. Due to limitations with regards to the availability local level housing market statistics that we match into the survey, we only use English and Welsh households. We discuss regional housing data in more detail below.

${ }^{6}$ We construct a core set of variables including age of the household head (in approximate 10-year age brackets), indicator variables for gender, marital status, whether the household includes dependent children, employment dummies (employed, unemployed, other) and dummy variable for whether the spouse or partner of the household head is employed. Education is measured by the age at which the household head completed full-time education. Financial variables include household gross annual income, total household savings in liquid products (excluding retirement saving) and total consumer credit debt.
} 


\subsection{Local Housing Market Variables}

We match into our survey data a set of variables that describe the housing market in the locality of the household. A range of studies show local housing market characteristics are important for explaining home ownership choices (Sinai and Souleles, 2005; Banks et al., 2016; Amior and Halket, 2014; Bostic and Lee, 2008). In total, we match five variables into our survey data at the local level: the regional house price to income ratio, home ownership rate and gross rental yield; and also at the postcode (i.e. zip code) level the 5-year house price growth rate and standard deviation of mean house prices ${ }^{7}$.

\subsection{Mortgage Financial Literacy Questions}

The main innovation in our study is the set of bespoke questions we added to measure financial literacy and behavioral characteristics. Our first set of questions comprises four questions that measure the 'mortgage financial literacy' of respondents. We follow the convention in studies of financial literacy by inserting short multiple-choice questions with objective answers, such as those used in studies on consumer credit and debt (Lusardi and Tufano, 2009; Disney and Gathergood, 2013) retirement saving (Lusardi and Mitchell, 2007a, 2007b; van Rooij et al., 2011a) and stock market participation (Guiso and Jappelli, 2005; van Rooij et al., 2011b).

A commonality across these studies is that the measure of financial literacy employed in the analysis allows the researcher to judge better and worse levels of financial understanding against objective criteria. Our financial literacy questions are specifically related to mortgage products. We focus on mortgages because our central interest is whether individuals do not become homeowners due to a lack of understanding of the mortgage market - engagement that is essential for nearly all households looking to become homeowners.

The four questions we design test respondents' understanding of a set of concepts that are integral to understanding the functioning of a mortgage. The first question tests whether the respondent understands that, ceteris paribus, the total cost of a mortgage is increasing with its duration. The second question requires a simple interest calculation. These two questions

\footnotetext{
7 The first three variables are regional due to availability of income and rental price data (nine English and Welsh regions), the other two variables are more granular to the postcode district level (84 England and Wales postcode districts). First, we calculate the house price to average income ratio in the region where the household is resident using house price data taken from the UK's official house price sales index and income data from the UK Office for National Statistics. Second, we match in the regional home ownership rate from UK Census data. Third, we match a measure of the average simple gross rental yield in the region of residence calculated by the financial consulting agency BM Solutions. For each household in our data we match in a 5-year house price index at the postcode district level based on official sales data from the England and Wales land registry. Using these data, we calculate the 5-year growth rate and 5-year standard deviation of mean house prices.
} 
together test whether respondents grasp the most basic features of a loan product. The third question tests understanding of compound finance ${ }^{8}$. The question is constructed in such a way that a respondent who understands the concept of compounding can identify the correct answer using elimination of incorrect answers using very basic math. The fourth question, which is the most challenging question, tests whether individuals can identify the amortization profile of a mortgage.

Each question was framed in the context of a particular dimension of typical mortgage contracts. Respondents could view multiple-choice answers to each question on screen in the online survey and were asked to select one answer from the set of available answers. The four questions (with the correct answer shown in italics) are:

1. Suppose a 15 year mortgage and a 30 year mortgage have the same Annual Percentage Rate and the same amount borrowed. The total amount repaid will be:

a. Higher for the 15 year mortgage; b. Higher for the 30 year mortgage;

c. The total amount repaid on both mortgages will be the same; d. Don't know

2. Suppose you owe $£ 50,000$ on a mortgage at an Annual Percentage Rate of $6 \%$. If you didn't make any payments on this mortgage how much would you owe in total after one year?

a. Less than $£ 50,000$; b. $£ 50,000$ - $£ 54,999$; c. $£ 55,000$ - $£ 59,999$;

d. $£ 60,000$ - $£ 64,999$; e. More than $£ 65,000$; f. Don’t know

3. Suppose you owe $£ 100,000$ on a mortgage at an Annual Percentage Rate of $5 \%$. If you didn't make any payments on this mortgage how much would you owe in total after five years?

a. Less than $£ 120,000$; b. Between $£ 120,000$ and $£ 125,000$;

c. More than $£ 125,000$; d. Don’t know

4. Suppose you owe $£ 200,000$ on a mortgage with an Annual Percentage Rate of $5 \%$. If you made annual payments of $£ 10,000$ per year how long would it take to repay the whole mortgage?

a. Less than 20 years; b. Between 20 and 30 years; c. Between 30 and 40 years; d. The mortgage would never be repaid; e. Don't know

From answers to the four questions we sum the number of correct answers to create a five-point financial literacy score, ranging from zero to four ${ }^{9}$.

\footnotetext{
${ }^{8}$ Importantly, the question does not require the respondent to make a compound interest calculation, which would be mathematically challenging, especially in a survey setting.

${ }^{9}$ We initially treat "don't know" as an incorrect answer. In our robustness analysis in Section 4 we show that our results are not sensitive to these "don't know" respondents.
} 
There are a number of reasons to think that financial literacy is endogenous to home ownership. Financial literacy may be correlated with individual characteristics we do not directly observe that also affect home ownership (such as parental income) and other elements of an individual's financial situation (such as inherited wealth). In addition, there may be reverse causality between housing tenure and financial literacy. Purchasing a home via a mortgage may cause individuals to gain financial literacy as they learn about their mortgage contract. Estimations that do not control for correlated errors typically underestimate the effect of financial literacy on economic outcomes (Christiansen et al., 2008; Behrman et al., 2012; Lusardi and Mitchell, 2007b).

Consequently, we adopt an IV regression model in which we instrument the respondent's financial literacy score. An ideal instrument should contain an exogenous source of variation in financial literacy that is unrelated to housing tenure. A wide variety of instruments are used in the literature, including parental education background (van Rooij et al., 2011b) and whether the respondent studied economics or finance in school (Lusardi and Tufano, 2009).

We had the opportunity to include an additional survey question for use as an instrument for financial literacy. Our choice was guided by Jappelli and Padula (2013), who review and test 11 instruments employed in the prior literature. They find only a subset of instruments pass the 'weak instruments' test of Stock and Yogo (2005) and conclude that the ideal instrument would be an individual's financial literacy measured before they entered labor and financial markets, that is before they made selective choices over financial behaviors that could give rise to a channel for reverse causality.

Pre-market financial literacy is typically unobserved, hence Jappelli and Padula (2013) suggest early-life mathematical ability as a proxy, specifically mathematical performance in primary school ${ }^{10}$. This instrument itself does have limitations: average ability will vary across schools with socio-economic factors and math performance may correlate with unobserved factors affecting home ownership apart from the formation of future financial literacy.

We adopt their survey question, which is as follows:

- When you were at primary school aged 10, how did you perform in maths compared to other children in your class?

a. Much better than average; b. Better than average; c. About the same as average; $d$. Worse than average; e. Much worse than average

\footnotetext{
${ }^{10}$ The exact question used by Jappelli and Padula (2013) is: "Now I would like you to think back to your time in school when you were 10 years old. How did you perform in Maths compared to other children in your class? Did you perform much better, better, about the same, worse or much worse than the average?"
} 
In the UK education system, 10 is the age before high school entry and hence before students are able to self-select into subjects of interest. From answers to this question we create a math level score ranging from one ('much worse') to five ('much better').

\subsection{Behavioral Characteristics Questions}

Behavioral characteristics other than financial literacy may be important for home ownership decisions and we add an additional set of questions into our survey that measure those. We focus on two characteristics: time preferences and risk attitude.

Time preference may be an important factor in determining home ownership decisions. Saving for down payments to meet lending criteria involves postponing non-housing consumption. We measure two aspects of time preference in the survey. First, we include a measure of patience using a short question developed by Dohmen et al. $(2010)^{11}$. The statement to proxy patience reads:

- "How do you see yourself: are you generally an impatient person, or someone who always shows great patience? Answers are coded on an 11-point scale, with 0 referring to 'very impatient' and 10 to 'very patient'."

Second, we include a measure of present bias. Recent studies have used survey measures of time preference to show that patience and present bias are important for a range of household outcomes including saving (Ameriks et al., 2007), human capital accumulation (Cadena and Keys, 2015) and behavior among adolescents (Sutter et al., 2013). We include separate measures of patience and present bias to distinguish between behaviors that might arise due to these different aspects of time preference ${ }^{12}$.

We elicit present bias using a question in which respondents associate or disassociate themselves with a short statement describing 'impulsive' consumption behavior on a five point Likert scale from 'agree strongly' to 'disagree strongly'. The statement is:

- "I am impulsive and tend to buy things even when I can't really afford them."

The final behavioral characteristic we measure in our survey is attitude to risk, which has

\footnotetext{
11 The authors insert this measure of patience into the German Socio-Economic Panel to investigate the relation between risk attitude, patience and cognitive ability. Vischer et al. (2013) use incentivized time preference elicitation methods on the same survey subject pool as in Dohmen et al. (2010) and find answers to the survey question closely match those of experimental methods.

12 How does present bias differ from patience? In models of intertemporal choice, the distinction is made between the rate at which an individual discounts future consumption ('patience') and whether the individual exhibits a bias towards immediate consumption ('present bias'). A common representation of present bias preferences is the $\beta$ - $\delta$ model of quasi-hyperbolic discounting (Laibson, 1997).
} 
been shown to be an important component of home ownership choices (Diaz-Serrano, 2005). We adopt the methodology of recent studies by including a proxy question in our survey. The question we use to measure risk aversion is developed and tested by Dohmen et al. (2011), who show survey answers correlate closely with measured risk preferences in experimental lab tasks. The question is:

- "How do you see yourself: are you generally a person who is fully prepared to take risks or do you try to avoid taking risks? Please tick a box on the scale, where the value 0 means: 'unwilling to take risks' and the value 10 means: 'fully prepared to take risks'."

\section{Summary Data Differences between Owners and Renters, Young and Old}

\subsection{Socio-Economic, Financial and Locality Characteristics}

Table 1 presents summary statistics for the socio-economic characteristics of sample. The sample comprises 1,205 households. In the sample, $65 \%$ of households are homeowners who either own their home with or without a mortgage ${ }^{13}$. Homeowners and renters differ as expected in average socio-economic characteristics. Homeowners are typically older, more likely to have a male household head and are more likely to be married and have children. Renters on average report a slightly higher age at which they left full-time education, partly reflecting cohort differences in the prevalence of college and university education (renters are on average younger than homeowners). Homeowners are more likely to be employed and have a partner or spouse in employment.

Financial characteristics of owners and renters also differ in patterns similar to those found in previous studies. Average household income is higher among owners by approximately $49 \%$. Owners and renters have very similar average levels of consumer credit debt. Non-pension savings are much higher among owners compared with renters. For homeowners, the average self-reported property value in the data is $£ 216,100$. The average value of mortgage debt among homeowners is approximately $£ 77,800$.

Further summary data on local housing market characteristics related to home ownership are provided in Table A1 in the Appendix. Summary data shows renters typically live in

\footnotetext{
${ }^{13}$ The full survey sample comprises approximately 1,600 households. We exclude retired households from the analysis. The home ownership rate in our sample is nearly identical to the aggregate England and Wales $66 \%$ home ownership rate (Source: UK Office for National Statistics).
} 
localities where house prices are on average higher (relative to income), rents are lower (relative to house prices) and house prices are more variable. Renters also live in localities where the 5-year standard deviation of mean house prices is considerably higher. These variables are important control variables in our regression analysis.

\subsection{Mortgage Financial Literacy}

Summary data for responses to the financial literacy questions are shown in Table 2. Overall, the pattern of correct responses to the questions confirms our hypothesis that the questions are increasing in difficulty. $70 \%$ of respondents answered the first question correctly and a little over half did so for the second question. The third and fourth questions, which test understanding of more complex concepts of interest compounding and balancing accrued interest against pay-downs, have much lower correct response rates. Approximately $40 \%$ of respondents answer Question 3 correctly and less than one third answer Question 4 correctly. The average literacy score of the sample, the sum of number of correct answers, is 1.97 .

Most wrong answers are due to respondents choosing an incorrect option and are not due to high rates of respondents answering "don't know" (which could indicate respondents disengaged with our survey questions). In the whole sample, $17 \%$ of respondents answered "don't know" to the first question. For later questions, the proportions of respondents answering "don't know" increases, but accounts for only part of the reduction in correct answers. Between questions one and four the proportion of respondents choosing the correct answer falls by 40 percentage points. The proportion of respondents choosing "don't know" increases by 12 percentage points. Therefore, at a maximum, "don't know" answers chosen due to disengagement with the survey could account for only one third of the increase in incorrect answers between the beginning and the end of the financial literacy questions module ${ }^{14}$.

Homeowners do much better in answering the financial literacy questions on average. The mean literacy score among homeowners is 2.13, compared with 1.69 among renters - a difference of 0.44 points equivalent to a $26 \%$ lower financial literacy of renters. For each question, the proportion of correct answers is higher for homeowners than for renters, with both groups showing the same pattern of higher proportions of correct responses to the earlier

\footnotetext{
${ }^{14}$ Later in our econometric analysis, we test the sensitivity of our findings to potentially disengaged respondents by excluding those who answered "don't know" to the first question or those who answered with "don't know" to three or more questions.
} 
questions compared with the later questions.

\subsection{Behavioral Characteristics}

Summary data for the set of survey questions measuring behavioral characteristics are shown in Table 3. In our whole sample the average self-reported degree on patience is 5.70 on a scale of $0-10$ (10 meaning 'very patient') with a median of 6.00 and a standard deviation of 2.56. This indicates respondents neither tend to self-identify as particularly patient or impatient. Respondents tend to be slightly more risk averse, with a sample mean of 4.42 (10 meaning 'fully prepared to take risks'). In the whole sample, respondents tend to strongly disassociate themselves to our measure of present bias. Only $14 \%$ of respondents tend to agree or agree strongly that they are impulsive in their spending behavior.

A comparison of homeowners and renters indicates only a small difference in the degree of patience. Homeowners self-report as, on average, being slightly less patient (5.62 compared with 5.85), though this difference is small compared with the standard deviation of around 2.5. The difference between groups with regards to risk attitude is similarly small: homeowners are slightly more risk averse (4.31) than renters (4.60). Among renters, a higher proportion, $19 \%$, self-identify as present biased, compared with $12 \%$ of home owners.

\subsection{Differences between Young and Old}

Next, we show unconditional differences between owners and renters across young and old age groups. As we show later in our econometric analysis, we find large differences in the relationship between financial literacy and home ownership across young and old groups. Table 4 summarizes differences between owners and renters for a range of financial variables, financial literacy questions and behavioral characteristics. P-values from t-tests for the equivalence of mean value of home owners and renters within each age group are reported in the table.

The summary data shows owners and renters differ in many characteristics in both young and old groups: owners have, on average, higher income, liquid savings and are less likely to be credit constrained. Owners also show higher average literacy scores. However, there are also differences in the comparisons between young and old households. Compared with young renters, young home owners are less likely to have suffered a recent income loss, show on average less willingness to take risks, lower self-reported patience and are less likely to identify as present biased. Differences in these variables are not statistically significant between old home owners and renters. Hence these results suggest some heterogeneity in the 
differing characteristics of home owners and renters across young and old age groups.

\section{Econometric Models and Estimation}

Our main interest is to estimate the effects of financial literacy on home ownership. The summary statistics suggest financial literacy positively relates to home ownership for both young and old households. Our regression analysis allows us to control for a range of covariates and also to control for the potential endogeneity of financial literacy to home ownership.

We first describe the empirical model of home ownership. The baseline econometric model we estimate is a probit model in which the dependent variable is a $1 / 0$ dummy that takes a value of 1 if the household is a homeowner and a value of 0 if the household is a renter $^{15}$. We include a wide range of covariates incorporating local housing market characteristics $(\mathrm{hm})$, behavioral characteristics $(\mathrm{bc})$ and our financial literacy index $(\mathrm{fl})$. The vector $\mathrm{X}$ includes a broad range of socio-economic controls. The model we estimate is then written as:

$$
\operatorname{Pr}(\text { Owner }=1)=\Phi\left(\alpha_{0}+\alpha_{1} h m+\alpha_{2} b c+\alpha_{3} f l+\mathbf{X}^{\prime} \beta\right)
$$

where $\Phi$ is the cumulative normal distribution. We estimate the model by maximum likelihood and calculate average marginal effects which we report in the results.

As discussed above, the performance of survey respondents in our financial literacy questions may arise endogenously with home ownership choices. Therefore, we instrument observed financial literacy using our measure of early-life mathematical ability following Jappelli and Padula (2013). We do so using a two-equation model in which the relation between financial literacy and mathematical ability is estimated by the equation:

$$
f l=\alpha_{0}+\alpha_{1} m a t h+\alpha_{2} h m+\alpha_{3} b c+\mathbf{X}^{\prime} \beta+u
$$

where math denotes the variable in our survey data which measures self-reported mathematical performance at school on a five-point scale. Equation 2 includes all the covariates that enter in Equation 1. We use an IV probit model that jointly estimates both equations using a maximum likelihood estimator. We acknowledge that this approach does not control for all forms of endogeneity and that unobserved factors might still in part explain the relationship we find between financial literacy and home ownership.

\footnotetext{
${ }^{15}$ We first estimate our models with a sample that classifies all respondents who own a home without a mortgage and those with a mortgage as 'homeowners'. We later show that our results are robust to excluding homeowners without mortgages.
} 


\subsection{Home ownership IV Probit Results}

Results from our baseline model are shown in Table 5. We show results for all households and for sub-samples of younger and older households. Our instrument performs strongly in the first-stage of the two-stage model (results from the first-stage model are shown in Appendix Table A2). The instrument is statistically significant in all specifications at the $0.1 \%$ level. Our econometric model has a single endogenous regressor and a single instrument, so following Staiger and Stock (1997) and Stock and Yogo (2005) we evaluate the F-statistic from the first-stage models, which are higher than a value of 10 in each case and higher than the critical values at the 5\% significance level provided by Stock and Yogo (2005).

Results from the second stage show the set of covariates in our model relate to home ownership in keeping with findings from the prior literature. The probability of home ownership increases with income among both younger and older households, but there is a concave home ownership gradient in income as low income households are much less likely to be homeowners. The coefficients on the income loss and credit constrained dummy variables are both negative, implying households who are captured by these dummy variables are less likely to be homeowners ${ }^{16}$. Among regional housing market variables, the coefficients on the 5-year growth and standard deviation of house prices are both significant at the $1 \%$ level, as is the local house price to average income ratio. The marginal effects imply a strong negative relationship between the level and volatility of house prices and the likelihood of home ownership ${ }^{17}$.

Turning to our main interest, results in Column 1 show the coefficient on the financial literacy score is positive and weakly statistically significant at the $10 \%$ level. The marginal effect of 0.022 implies a one standard deviation increase in the financial literacy score (1.97 units) raises the likelihood of home ownership by 4.3 percentage points. Evaluated against a baseline predicted probably of 0.647 this is a $6.5 \%$ increase in likelihood.

However, results in Columns 2 and 3 show that financial literacy is important for home ownership only among the young. The coefficient on the financial literacy score is positive

\footnotetext{
16 The coefficient on the recent income loss dummy is statistically significant at the $10 \%$ level and the coefficient on the credit constrained dummy is significant at the $1 \%$ level. The marginal effect on the credit constrained dummy coefficient takes a value of -0.124 , which implies a credit constrained household is 12.4 percentage points less likely to own a home. Against a baseline probability of $70 \%$ this is an $18 \%$ reduction in the likelihood of home ownership due to credit constraints.

${ }^{17}$ A one-unit increase in the house price to income ratio lowers the likelihood of home ownership by 12 percentage points. A one standard deviation increase in house price volatility lowers the likelihood of home ownership by 2.7 percentage points. The coefficient on the 5 -year growth of house prices is positive and highly significant, implying individuals are more likely to own homes in localities with stronger house price growth.
} 
and statistically significant at the $1 \%$ level of the sample of young households but statistically not significant for the sample of old households. Given the lower home ownership rate among young households, the implied effect of a one-unit increase in financial literacy $(1.36$ units) is to raise the home ownership rate among young households by $(0.027 / 0.513)=5.3 \%$. To compare this effect size, the equivalent increase in income among young households required to raise home ownership by $5.3 \%$ is approximately $£ 5,000$ per year.

Results in Columns 2 and 3 also show our measure of present bias is important for home ownership decisions of young, but not old, households. The coefficient on the present bias dummy variable is negative and statistically significant at the 5\% level. The coefficient magnitude implies a household that reports present bias is $8.7 \mathrm{pp}$ less likely to be a home owner, or a $17 \%$ reduction. However, with only $17 \%$ of young households reporting present bias a one-unit increase is a very large change within the sample.

\subsection{Home ownership IV Probit Sensitivity Tests}

We have undertaken sensitivity tests for our IV specification. Results are potentially sensitive to the inclusion of "don't know" answers, which might indicate households were disengaged from part of our survey. Coding these answers as 'incorrect' might introduce misclassification bias into our estimates. Therefore, in Table 6 we re-estimate the IV Probit models excluding observations where respondents answered "don't know" to the first question (the easiest question), or answered at least three questions with "don't know". This removes 279 observations from our sample, but the pattern of results is unchanged. In the whole sample the financial literacy variable remains positive, but its statistical significant is now below the $10 \%$ level. However, the coefficient estimate remains statistically significant at the $1 \%$ level among the sample of young households, but is not different from zero for older households. The marginal effect implies a slightly higher proportionate effect of a oneunit increase in the financial literacy score of $(0.035 / 0.515)=6.8 \%$. We also test the sensitivity of our results to the exclusion of home owners without mortgages in Appendix Table A3. Results there also show the same pattern that financial literacy is important for home ownership among the young sample, but unrelated to home ownership among the old sample.

\subsection{Financial Literacy and Mortgage Characteristics of Young Households}

In this section, we investigate how financial literacy affects the mortgage choices of households. Results from the previous section show that poor financial literacy lowers the 
likelihood of younger households owning their homes. However, even among young homeowners, poor financial literacy might affect mortgage choices. Households with less understanding of mortgage products may be more exposed to taking on riskier mortgages. For example, AMPs offer some features such as 'interest only' terms or slower amortization, which could be attractive to households who do not fully understand mortgage terms and misinterpret the initial benefits of these products.

To investigate this, we use additional data from our survey that relates to the characteristics of the mortgage taken on by the household. We construct various measures of the household's mortgage position: i) the loan-to-value ratio, calculated as the total value of the mortgage principal divided by the house value; ii) the loan-to-income ratio, calculated as the total value of the mortgage principal divided by annual household income, iii) an indicator variable for whether the household has recently refinanced their mortgage within the last three years; and indicator variables for whether the mortgage held by the household is iv) an AMP instead of a standard mortgage product and v) an adjustable rate mortgage instead of a fixed rate mortgage. We classify a mortgage product as a standard mortgage if the monthly repayments cover the interest and principal such that the mortgage amortizes over a defined lifetime. In the UK, these are known as 'capital repayment' mortgages. We classify a mortgage product as an alternative mortgage is the initial payment only covers the interest due, or less than the interest due (negative amortization). In our sample, among the 339 younger home owners, 27\% refinanced within the past 3 years, 15\% hold an AMP and 44\% hold an adjustable rate mortgage (Table 4).

Using this set of outcome variables, we estimate a variety of econometric models. Our econometric models address two forms of endogeneity. First, the performance of survey respondents in our financial literacy questions may arise endogenously with mortgage choices (as with home ownership choices). Therefore, we instrument financial literacy following the IV strategy used in the models for home ownership above. Second, we only observe mortgage choices for households who use a mortgage to buy a home. In our sample, $91 \%$ of young home owners hold a mortgage, but nevertheless there is potential selection bias if financial literacy is related to the decision to use a mortgage to buy a home instead of making a purchase without a mortgage. To address this problem, we use a selectivity correction model where the local house price to income ratio is included as an exclusion restriction. This exclusion restriction is used on the basis that higher house prices in the locality relative to individual incomes make it more likely that a young household will require a mortgage to fund their home purchase. 
The resulting econometric model, therefore, involves a selectivity correction equation that predicts whether the household holds a mortgage and an IV correction for the financial literacy score of the household. This 'hybrid' approach is implemented by calculating the Inverse Mills Ratio (IMR) from the selection equation and including it as an additional covariate in the IV models (see Amemiya, 1985, for a discussion of this econometric approach).

The basic Heckman selectivity correction probit model for mortgage borrowing with sample correction can be written as:

$$
\begin{aligned}
\text { mortgage characteristic } & =1\left[\beta_{0}+\beta_{1} f l+\mathbf{X}^{\prime} \beta+u>0\right] \\
\text { mortgage holder } & =1\left[\beta_{0}+\beta_{1} f l+\beta_{1} l h p i+\mathbf{X}^{\prime} \omega+v>0\right]
\end{aligned}
$$

where (4) is the sample selection equation. We use equation (3) with the five different binary outcome variables for mortgage characteristics described above ${ }^{18}$. The binary outcome variables describing mortgage characteristics are only observed when mortgage holder $=1$. $f l$ is the continuous measure of financial literacy and $\mathbf{X}^{\prime}$ a vector of demographic and financial control variables. lhpi is the local house price to income ratio and is included as the exclusion restriction for the selectivity correction. The two equations are jointly estimated using maximum likelihood.

The hybrid of a Heckman selectivity correction model and an IV probit model and can then be written as:

$$
\begin{aligned}
f l & =\beta_{0}+\beta_{1} \text { math }+\beta_{2} I M R+\mathbf{X}^{\prime} \beta+\varepsilon \\
\text { mortgage characteristics } & =1\left[\beta_{0}+\beta_{1} f l+\beta_{2} I M R+\mathbf{X}^{\prime} \beta+\mu>0\right]
\end{aligned}
$$

where math is the level of math whilst in school, which we use as instrument for financial literacy as in Equations 1 and 2. IMR is the 'Inverse Mills Ratio', which is the sample selection correction term of the Heckman selectivity correction ${ }^{19}$. This means that this hybrid approach is implemented by calculating the inverse mills ratio from the selection equation (4) and including it as an additional covariate in an IV probit model. Equations 5 and 6 are then jointly estimated using maximum likelihood estimation.

\footnotetext{
${ }^{18}$ We transform the continuous loan-to-value (ltv) ratio to a binary variable that is 1 when the ltv of the household is larger than the 75th percentile in the distribution. The loan-to-income ratio (lti) of the household is similarly transformed to a binary variable that is one if lti is larger than the 75th percentile in the distribution.

19 The IMR or 'hazard rate' is the ratio of the probability density function and the cumulative distribution function evaluated at the predicted outcomes of (4), divided by the standard error of (4).
} 


\subsection{Mortgage Characteristics IV-Heckman Estimates}

Table 7 shows results for the models where the outcome variables are the loan-to-value ratio (Column 1) and loan-to-income ratio (Column 2). In both models the coefficient on the IMR is negative and statistically significant at the $1 \%$ level. This implies the selectivity correction is significant in the regression: if we fail to correct for selection into holding a mortgage the coefficient slopes would be flatter and the betas underestimated. In the IV component of the model the coefficient on the instrument for financial literacy (the financial education at school index) is statistically significant at the $1 \%$ level, with an F-statistic from the regression of 24.660 .

Results show the coefficient on the instrumented financial literacy score is negative and significant at the $1 \%$ level in Column 1 and at the 5\% level in Column 2. The negative coefficient values imply a young household with better financial literacy, conditional upon holding a mortgage, will hold a mortgage with lower mortgage debt (relative to the value of the house and relative to their income). The coefficient values imply a 1 unit increase in the financial literacy score lowers the probability of the household holding a high loan-to-value ratio by $1.6 \mathrm{pp}$, or $(0.016 / 0.213)=7.5 \%$. The same increase in financial literacy lowers the probability of the household holding a high loan-to-income ratio by $1.1 \mathrm{pp}$ or $(0.011 / 0.155)=$ $7.1 \%$.

To test the sensitivity of our results to the econometric specification used, we have also estimated models which exclude the selectivity correction, but retain the instrument for financial literacy (results are shown in Table A4). Therefore, in these specifications we estimate the effect of financial literacy on mortgage characteristics, conditional upon holding a mortgage. In those models the implied effect of a one-unit increase in financial literacy is to lower the probability of holding a high loan-to-value ratio by $2.6 \%$ and the probability of holding a high loan-to-income ratio by $7.1 \%$. Hence, while it is important to control for selection into mortgage holding, our results are not sensitive to this econometric setup.

Why do we observe a negative effect of financial literacy on the level of household debt? One explanation is that our instrument may be correlated with unobserved factors which cause the household to have lower debt, such as individual- or parental wealth, which we cannot control for directly in our econometric model. An alternative explanation is that less financially literate mortgage holders are steered towards higher leverage products which are more profitable to lenders. We find no evidence that financial literacy increases leverage, which would be the case if young homeowners were purchasing housing for investment 
returns and seeking to maximize the value of their home purchase through higher debt.

Results from the models in Table 8 further show that financial literacy is important for characteristics of the mortgage product used and also for household refinancing behavior. In Column 1 the outcome variable is whether the household refinanced their mortgage in the past 3 years. The results show the coefficient on the financial literacy score is negative and statistically significant at the 5\% level. The negative value implies households with higher financial literacy scores are less likely to have recently refinanced their mortgage - a one-unit increase in the financial literacy score implies a $(0.015 / 0.134)=12 \%$ reduction in the likelihood of a recent refinance. This might appear puzzling, as in the US mortgage market failure to refinance is often considered a sign of financial illiteracy (for example, see Deng et al., 2000). However, in the UK context the benefits of regular mortgage refinancing are more ambiguous as most mortgages are adjustable rate mortgages with short-term teaser rate discounts. More literate mortgage holders may be less likely to take short-term deals and in doing so avoid regularly paying refinancing fees.

Results in Columns 2 and 3 also show statistically significant effects of financial literacy. The coefficient on the financial literacy variables in the model for holding an AMP (instead of a standard repayment mortgage) in Column 2 is negative and statistically significant at the 5\% level. The marginal effect implies a one-unit increase in financial literacy lowers the likelihood of holding an AMP by $(0.042 / 0.072)=58 \%$ and raises the likelihood of holding an adjustable rate mortgage (instead of a fixed rate mortgage) by $(0.020 / 0.224)=8.9 \%$ in Column 3. We obtain similar results in most models if we estimate a model which excludes the selectivity correction, but retains the instrument for financial literacy. The implied effects of a one-unit increase in financial literacy are to lower the likelihood of recent refinancing by $6.3 \%$ (though the marginal effect is no longer statistically significant in this model), lower the likelihood of holding an AMP by $47.3 \%$ and raise the likelihood of holding an adjustable rate mortgage by $6.1 \%$. Full results are shown in Table A5.

We have undertaken further sensitivity analysis for the models with selectivity correction, with results reported in Appendix Tables A6 and A7. When we remove "don't know" answers from the sample the pattern of results remains unchanged for the loan-tovalue and loan-to-income models (Table A6) and the models for mortgage refinancing, mortgage repayment type and interest rate type (Table A7).

Taken together these results show financial literacy is important for the mortgage choices of young households. It is perhaps concerning that households with lower financial literacy take on more debt and are more likely to use alternative products that require foresight and 
future decisions on the part of the household (unlike standard mortgages that amortize in the background). We cannot conclude that households are making 'bad' choices, but instead interpret these results cautiously. Prior work has identified that pre-mortgage counseling can reduce delinquency (Hirad et al., 2001), potentially by raising households' awareness of the riskiness of some mortgage products.

\section{Conclusion}

In this paper, we use a specially commissioned bespoke consumer survey covering a representative sample of households in England and Wales to examine the relationship between financial literacy and home ownership. Financial literacy may be particularly important for explaining the age-home ownership gradient. We use four financial literacy questions together with a broad range of control variables and measures of behavioral characteristics and estimate instrumental variable probit models that explain home ownership status and also a range of models that explain mortgage choices. Our instrumental variable strategy addresses the potential endogeneity of financial literacy to mortgage market behavior. However, there may be other unobserved factors pertaining to home ownership that correlate with our instrument, such as parental wealth and bequests. Hence, unobserved factors might still in part explain the relationship we find.

Our results show that financial literacy is important for home ownership among the younger households but not for older households, consistent with financial literacy being an important determinant of the timing of transition into home ownership. Further results show financial literacy affects mortgage choices of the young, which may have important longerterm effects on the financial positions of young households entering the mortgage market. 


\section{References}

Aalbers, M.B. (2004). Promoting home ownership in a social rented city: policies, practices and pitfalls. Housing Studies, 19(3), 483-495.

Agarwal, S., Amromin, G., Ben-David, I., Chomsisengphet, S., and Evanoff, D.D. (2014). Predatory lending and the subprime crisis. Journal of Financial Economics, 113(1), 2952.

Agarwal, S., Driscoll, J.C., and Laibson, D.I. (2013). Optimal Mortgage Refinancing: A Closed-Form Solution. Journal of Money, Credit and Banking, 45(4), 591-622.

Amemiya, T. (1985). Advanced Econometrics. Cambridge, MA: Harvard University Press.

Ameriks, J., Caplin, A., Leahy, J., and Tyler, T. (2007). Measuring Self-Control Problems. American Economic Review, 97(3), 966-972.

Amior, M. and Halket, J. (2014). Do households use home-ownership to insure themselves? Evidence across U.S. cities. Quantitative Economics, 5(3), 631-674.

Banks, J., Blundell, R., Oldfield, Z., and Smith, J.P. (2016). House Price Volatility and the Housing Ladder. In D. A. Wise (Ed.), Insights in the Economics of Aging (forthcoming). Chicago: University of Chicago Press.

Behrman, J.R., Mitchell, O.S., Soo, C.K., and Bravo, D. (2012). How Financial Literacy Affects Household Wealth Accumulation. American Economic Review, 102(3), 300-304.

Benito, A. and Mumtaz, H. (2009). Excess Sensitivity, Liquidity Constraints, And The Collateral Role Of Housing. Macroeconomic Dynamics, 13(3), 305-326.

Bond, P., Musto, D.K., and Yilmaz, B. (2009). Predatory mortgage lending. Journal of Financial Economics, 94(3), 412-427.

Bostic, R.W. and Lee, K.O. (2008). Mortgages, Risk, and Homeownership among Low- and Moderate-Income Families. American Economic Review, 98(2), 310-314.

Bucks, B. and Pence, K. (2008). Do borrowers know their mortgage terms? Journal of Urban Economics, 64(2), 218-233.

Cadena, B.C. and Keys, B.J. (2015). Human Capital and the Lifetime Costs of Impatience. American Economic Journal: Economic Policy, 7(3), 126-153.

Campbell, J.Y. (2006). Household Finance. The Journal of Finance, 61(4), 1553-1604.

Chambers, M., Garriga, C., and Schlagenhauf, D.E. (2009). Accounting For Changes In The 
Homeownership Rate. International Economic Review, 50(3), 677-726.

Charles, K.K. and Hurst, E. (2002). The Transition to Home Ownership and the Black-White Wealth Gap. Review of Economics and Statistics, 84(2), 281-297.

Christiansen, C., Joensen, J.S., and Rangvid, J. (2008). Are Economists More Likely to Hold Stocks? Review of Finance, 12(3), 465-496.

Collins, W.J. and Margo, R.A. (2011). Race and Home Ownership from the End of the Civil War to the Present. American Economic Review, 101(3), 355-359.

Coulson, N.E. and Li, H. (2013). Measuring the external benefits of homeownership. Journal of Urban Economics, 77, 57-67.

Deng, Y., Quigley, J.M., and van Order, R. (2000). Mortgage Terminations, Heterogeneity and the Exercise of Mortgage Options. Econometrica, 68(2), 275-307.

Diaz-Serrano, L. (2005). On the negative relationship between labor income uncertainty and homeownership: Risk-aversion vs. credit constraints. Journal of Housing Economics, 14(2), 109-126.

Dietz, R.D. and Haurin, D.R. (2003). The social and private micro-level consequences of homeownership. Journal of Urban Economics, 54(3), 401-450.

DiPasquale, D. and Glaeser, E.L. (1999). Incentives and Social Capital: Are Homeowners Better Citizens? Journal of Urban Economics, 45(2), 354-384.

Disney, R. and Gathergood, J. (2013). Financial literacy and consumer credit portfolios. Journal of Banking \& Finance, 37(7), 2246-2254.

Dohmen, T., Falk, A., Huffman, D., and Sunde, U. (2010). Are Risk Aversion and Impatience Related to Cognitive Ability? American Economic Review, 100(3), 1238-1260.

Dohmen, T., Falk, A., Huffman, D., Sunde, U., Schupp, J., and Wagner, G.G. (2011). Individual Risk Attitudes: Measurement, Determinants, and Behavioral Consequences. Journal of the European Economic Association, 9(3), 522-550.

Engelhardt, G. V., Eriksen, M.D., Gale, W.G., and Mills, G.B. (2010). What are the social benefits of homeownership? Experimental evidence for low-income households. Journal of Urban Economics, 67(3), 249-258.

Fetter, D.K. (2013). How Do Mortgage Subsidies Affect Home Ownership? Evidence from the Mid-century GI Bills. American Economic Journal: Economic Policy, 5(2), 111-47.

Gabriel, S.A. and Rosenthal, S.S. (2015). The Boom, the Bust and the Future of 
Homeownership. Real Estate Economics, 43(2), 334-374.

Gathergood, J. and Weber, J. (2015). Financial Literacy, Present Bias and Alternative Mortgage Products. SSRN Electronic Journal.

Glaeser, E.L. and Shapiro, J.M. (2003). The Benefits of the Home Mortgage Interest Deduction. In J. M. Poterba (Ed.), NBER Book Series: Tax Policy and the Economy (Vol. 17, pp. 37-82). MIT Press.

Grinstein-Weiss, M., Sherraden, M., Gale, W.G., Rohe, W.M., Schreiner, M., and Key, C. (2013). Long-Term Impacts of Individual Development Accounts on Homeownership among Baseline Renters: Follow-Up Evidence from a Randomized Experiment. American Economic Journal: Economic Policy, 5(1), 122-145.

Guiso, L. and Jappelli, T. (2005). Awareness and Stock Market Participation. Review of Finance, 9(4), 537-567.

Haurin, D.R., Hendershott, P.H., and Wachter, S.M. (1997). Borrowing Constraints and the Tenure Choice of Young Households. Journal of Housing Research, 8(2), 137-154.

Haurin, D.R. and Morrow-Jones, H.A. (2006). The Impact of Real Estate Market Knowledge on Tenure Choice: A Comparison of Black and White Households. Housing Policy Debate, 17(4), 625-653.

Haurin, D.R., Parcel, T.L., and Haurin, R.J. (2002). Does homeownership affect child outcomes? Real Estate Economics, 30(4), 635-666.

Haurin, D.R. and Rosenthal, S.S. (2007). The Influence of Household Formation on Homeownership Rates Across Time and Race. Real Estate Economics, 35(4), 411-450.

Hirad, A., Zorn, P.M., and Mac, F. (2001). A Little Knowledge Is a Good Thing: Empirical Evidence of the Effectiveness of Pre-Purchase Homeownership Counseling.

Ho, G. and Pennington-Cross, A. (2006). The impact of local predatory lending laws on the flow of subprime credit. Journal of Urban Economics, 60(2), 210-228.

Jappelli, T. and Padula, M. (2013). Investment in financial literacy and saving decisions. Journal of Banking \& Finance, 37(8), 2779-2792.

Kolodziejczyk, C. and Leth-Petersen, S. (2013). Do First-Time House Buyers Receive Financial Transfers from Their Parents? Scandinavian Journal of Economics, 115(4), 1020-1045.

Laibson, D. (1997). Golden Eggs and Hyperbolic Discounting. The Quarterly Journal of 
Economics, 112(2), 443-478.

Lusardi, A. and Mitchell, O.S. (2007a). Baby Boomer retirement security: The roles of planning, financial literacy, and housing wealth. Journal of Monetary Economics, 54(1), $205-224$.

Lusardi, A. and Mitchell, O.S. (2007b). Financial Literacy and Retirement Preparedness: Evidence and Implications for Financial Education. Business Economics, 42(1), 35-44.

Lusardi, A. and Tufano, P. (2009). Debt Literacy, Financial Experiences, and Overindebtedness. NBER Working Paper, 14808.

Ortalo-Magné, F. and Sven, R. (2006). Housing market dynamics: On the contribution of income shocks and credit constraints. Review of Economic Studies, 73(2), 459-485.

Sanders, A.B. (2005). Barriers to homeownership and housing quality: The impact of the international mortgage market. Journal of Housing Economics, 14(3), 147-152.

Sinai, T. and Souleles, N.S. (2005). Owner-Occupied Housing as a Hedge Against Rent Risk. The Quarterly Journal of Economics, 120(2), 763-789.

Staiger, D. and Stock, J. (1997). Instrumental Variables Regression with Weak Instruments. Econometrica, 65(3), 557-586.

Stock, J. and Yogo, M. (2005). Testing for Weak Instruments in Linear IV Regression. Identification and Inference for Econometric Models.

Sutter, M., Kocher, M.G., Glätzle-Rützler, D., and Trautmann, S.T. (2013). Impatience and Uncertainty: Experimental Decisions Predict Adolescents' Field Behavior. American Economic Review, 103(1), 510-531.

van Rooij, M., Lusardi, A., and Alessie, R.J.M. (2011a). Financial literacy and retirement planning in the Netherlands. Journal of Economic Psychology, 32(4), 593-608.

van Rooij, M., Lusardi, A., and Alessie, R.J.M. (2011b). Financial literacy and stock market participation. Journal of Financial Economics, 101(2), 449-472.

Vischer, T., Dohmen, T., Falk, A., Huffman, D., Schupp, J., Sunde, U., and Wagner, G.G. (2013). Validating an ultra-short survey measure of patience. Economics Letters, 120(2), $142-145$. 
Table 1: Sample Characteristics, Mean Values (Median Values)

\begin{tabular}{|c|c|c|c|}
\hline & $\begin{array}{c}(1) \\
\text { Full } \\
\text { Sample }\end{array}$ & $\begin{array}{c}\text { (2) } \\
\text { Homeowner }\end{array}$ & $\begin{array}{c}\text { (3) } \\
\text { Renter }\end{array}$ \\
\hline \multicolumn{4}{|l|}{ Age } \\
\hline $18-34(=1)$ & 0.29 & 0.18 & 0.49 \\
\hline $35-44(=1)$ & 0.24 & 0.26 & 0.21 \\
\hline $45-54(=1)$ & 0.24 & 0.29 & 0.16 \\
\hline $55+(=1)$ & 0.23 & 0.28 & 0.14 \\
\hline \multicolumn{4}{|l|}{ Demographics } \\
\hline Male $(=1)$ & 0.48 & 0.49 & 0.46 \\
\hline Married/living as married $(=1)$ & 0.64 & 0.76 & 0.42 \\
\hline Dependent children $(=1)$ & 0.28 & 0.31 & 0.21 \\
\hline Math level in school (1-5) & 3.60 & 3.59 & 3.61 \\
\hline Education leaving age (years) & 18.86 & 18.81 & 18.94 \\
\hline \multicolumn{4}{|l|}{ Employment } \\
\hline Employed (= 1) & 0.79 & 0.85 & 0.68 \\
\hline Unemployed (= 1) & 0.03 & 0.02 & 0.07 \\
\hline Student/Housewife/Disabled $(=1)$ & 0.18 & 0.13 & 0.25 \\
\hline Spouse employed $(=1)$ & 0.48 & 0.59 & 0.29 \\
\hline \multicolumn{4}{|l|}{ Household Finances } \\
\hline Household income $(\mathfrak{f})$ & $\begin{array}{c}36700 \\
(32400)\end{array}$ & $\begin{array}{c}41500 \\
(36000)\end{array}$ & $\begin{array}{c}27900 \\
(25000)\end{array}$ \\
\hline Consumer credit debt $(£)$ & $\begin{array}{c}2300 \\
(0)\end{array}$ & $\begin{array}{c}2400 \\
(0)\end{array}$ & $\begin{array}{c}2000 \\
(0)\end{array}$ \\
\hline Liquid savings $(\mathfrak{f})$ & $\begin{array}{c}8500 \\
(0)\end{array}$ & $\begin{array}{c}11300 \\
(0)\end{array}$ & $\begin{array}{c}3500 \\
(0)\end{array}$ \\
\hline Property value $(£)$ & $\begin{array}{c}139700 \\
(110000)\end{array}$ & $\begin{array}{c}216100 \\
(180000)\end{array}$ & $\begin{array}{c}0 \\
(0)\end{array}$ \\
\hline Mortgage outstanding amount $(\mathfrak{f})$ & $\begin{array}{c}50300 \\
(0)\end{array}$ & $\begin{array}{c}77800 \\
(62000)\end{array}$ & $\begin{array}{c}0 \\
(0)\end{array}$ \\
\hline \multicolumn{4}{|l|}{ Financial Circumstances } \\
\hline Recent income loss $(=1)$ & 0.16 & 0.14 & 0.18 \\
\hline Credit constrained $(=1)$ & 0.08 & 0.04 & 0.14 \\
\hline Observations & 1205 & 779 & 426 \\
\hline
\end{tabular}

Note: Table shows summary statistics for all individuals in the survey (Column 1), plus for all individuals divided into two mutually exclusive and exhaustive groups: those owning a home (either with or without a mortgage) in Column 2 and those renting in Column 3. The variable 'math level in school' is the individual's self-reported mathematical ability at school on a scale from 1 (much worse than average) to 5 (much better than average). Mean values reported, medians in parentheses for financial variables. 
Table 2: Mortgage Literacy Performance

\begin{tabular}{|c|c|c|c|}
\hline & $\begin{array}{l}\text { (1) } \\
\text { Full } \\
\text { Sample }\end{array}$ & Homeowner & $\begin{array}{c}(3) \\
\text { Renter }\end{array}$ \\
\hline \multicolumn{4}{|c|}{$\begin{array}{l}\text { 1. Suppose a } 15 \text { year mortgage and a } 30 \text { year mortgage have the same Annual Percentage } \\
\text { Rate and the same amount borrowed. The total amount repaid will be: }\end{array}$} \\
\hline Higher for the 15 year mortgage & 0.04 & 0.04 & 0.04 \\
\hline Higher for the 30 year mortgage & 0.70 & 0.75 & 0.61 \\
\hline The total amount repaid will be the same & 0.09 & 0.08 & 0.12 \\
\hline Do not know & 0.17 & 0.13 & 0.23 \\
\hline \multicolumn{4}{|c|}{$\begin{array}{l}\text { 2. Suppose you owe } £ 50,000 \text { on a mortgage at an Annual Percentage Rate of } 6 \% \text {. If you didn't } \\
\text { make any payments on this mortgage how much would you owe in total after one year? }\end{array}$} \\
\hline Less than $£ 50,000$ & 0.03 & 0.03 & 0.04 \\
\hline$£ 50,000-£ 54,999$ & 0.56 & 0.60 & 0.49 \\
\hline$£ 55,000-£ 59,999$ & 0.13 & 0.13 & 0.14 \\
\hline$£ 60,000-£ 64,999$ & 0.02 & 0.02 & 0.03 \\
\hline More than $£ 65,000$ & 0.04 & 0.04 & 0.03 \\
\hline Do not know & 0.22 & 0.19 & 0.27 \\
\hline \multicolumn{4}{|c|}{$\begin{array}{l}\text { 3. Suppose you owe } £ 100,000 \text { on a mortgage at an Annual Percentage Rate of } 5 \% \text {. If you } \\
\text { didn't make any payments on this mortgage how much would you owe in total after five } \\
\text { years? }\end{array}$} \\
\hline Less than $£ 120,000$ & 0.14 & 0.14 & 0.15 \\
\hline Between $£ 120,000$ and $£ 125,000$ & 0.22 & 0.21 & 0.23 \\
\hline More than $£ 125,000$ & 0.42 & 0.46 & 0.34 \\
\hline Do not know & 0.22 & 0.19 & 0.27 \\
\hline \multicolumn{4}{|c|}{$\begin{array}{l}\text { 4. Suppose you owe } £ 200,000 \text { on a mortgage with at an Annual Percentage Rate of } 5 \% \text {. If you } \\
\text { made annual payments of } £ 10,000 \text { per year how long would it take to repay the whole } \\
\text { mortgage? }\end{array}$} \\
\hline Less than 20 years & 0.03 & 0.02 & 0.03 \\
\hline Between 20 and 30 years & 0.27 & 0.28 & 0.24 \\
\hline Between 30 and 40 years & 0.11 & 0.11 & 0.13 \\
\hline The mortgage would never be repaid & 0.30 & 0.32 & 0.25 \\
\hline Do not know & 0.29 & 0.26 & 0.35 \\
\hline Literacy score $(0-4)$ & 1.97 & 2.13 & 1.69 \\
\hline Observations & 1205 & 779 & 426 \\
\hline
\end{tabular}

Note: Table shows breakdown of answers to financial literacy questions by proportion of respondents choosing each answer. Correct answers in italics. Column 1 shows statistics for whole sample, Column 2 for homeowners only and Column 3 for renters only. 
Table 3: Behavioral Characteristics

\section{(1)}

(2)

(3)

Full
Sample

Homeowner Renter

Patience: "Are you generally an impatient person, or someone who always shows great patience? Answers are coded on an 11-point scale, with '0' referring to 'very impatient' and '10' to 'very patient'."

Patience (0-10)

$\begin{array}{ccc}5.70 & 5.62 & 5.85 \\ (6.00) & (6.00) & (6.00) \\ {[2.56]} & {[2.61]} & {[2.47]}\end{array}$

Risk attitude: "Are you generally a person who is fully prepared to take risks or do you try to avoid taking risks? Please tick a box on the scale, where the value 0 means: 'unwilling to take risks' and the value 10 means: 'fully prepared to take risks'”

Risk attitude $(0-10)$

$\begin{array}{ccc}4.42 & 4.31 & 4.60 \\ (5.00) & (4.00) & (5.00) \\ {[2.33]} & {[2.30]} & {[2.39]}\end{array}$

Present biased: "I am impulsive and tend to buy things even when I can't really afford them."

\begin{tabular}{llll} 
Agree strongly & 0.03 & 0.02 & 0.04 \\
Tend to agree & 0.12 & 0.10 & 0.15 \\
Neither agree nor disagree & 0.20 & 0.19 & 0.20 \\
Tend to disagree & 0.30 & 0.30 & 0.30 \\
Disagree strongly & 0.33 & 0.36 & 0.27 \\
Don't know & 0.03 & 0.02 & 0.04 \\
Present biased $(=1)^{\mathrm{a}}$ & 0.14 & 0.12 & 0.19 \\
\hline Observations & 1205 & 779 & 426 \\
\hline
\end{tabular}

a 'Present biased' = 1 if answer 'agree strongly' or 'tend to agree', and = 0 otherwise.

Note: Table shows breakdown of answers to behavioral characteristics questions by proportion of respondents choosing each answer. Column 1 shows statistics for whole sample, Column 2 for homeowners only and Column 3 for renters only. Mean values reported, medians in parentheses and standard deviations in square brackets. 
Table 4: Characteristics of Young vs. Old Households, Mean Values (Median Values)

\begin{tabular}{|c|c|c|c|c|c|c|}
\hline & \multicolumn{3}{|c|}{ Young Households } & \multicolumn{3}{|c|}{ Old Households } \\
\hline & $(1)$ & $(2)$ & (3) & (4) & (5) & (6) \\
\hline & Homeowner & Renter & $p$-values & Homeowner & Renter & $p$-values \\
\hline \multicolumn{7}{|l|}{ Household Finances } \\
\hline Household income $(\mathfrak{f})$ & $\begin{array}{c}46318 \\
(40000)\end{array}$ & $\begin{array}{c}30375 \\
(26906)\end{array}$ & 0.000 & $\begin{array}{c}37756 \\
(34000)\end{array}$ & $\begin{array}{c}22092 \\
(20000)\end{array}$ & 0.000 \\
\hline Consumer credit debt $(\mathfrak{f})$ & $\begin{array}{l}2648 \\
(0)\end{array}$ & $\begin{array}{c}1773 \\
(0)\end{array}$ & 0.073 & $\begin{array}{c}2208 \\
(0)\end{array}$ & $\begin{array}{c}2457 \\
(0)\end{array}$ & 0.727 \\
\hline Liquid savings $(\mathfrak{f})$ & $\begin{array}{c}8136 \\
(0)\end{array}$ & $\begin{array}{c}4013 \\
(0)\end{array}$ & 0.008 & $\begin{array}{c}13710 \\
(0)\end{array}$ & $\begin{array}{c}2355 \\
(0)\end{array}$ & 0.000 \\
\hline \multicolumn{7}{|l|}{ Mortgage Characteristics } \\
\hline Property value $(\mathfrak{f})$ & $\begin{array}{c}198840 \\
(165000)\end{array}$ & $\begin{array}{c}0 \\
(0)\end{array}$ & - & $\begin{array}{c}229322 \\
(190000)\end{array}$ & $\begin{array}{c}0 \\
(0)\end{array}$ & - \\
\hline Mortgage outstanding amount $(\mathfrak{f})$ & $\begin{array}{c}118620 \\
(105000)\end{array}$ & $\begin{array}{c}0 \\
(0)\end{array}$ & - & $\begin{array}{c}46360 \\
(20000)\end{array}$ & $\begin{array}{c}0 \\
(0)\end{array}$ & - \\
\hline Refinanced within past 3 years $(=1)$ & 0.27 & 0.00 & - & 0.08 & 0.00 & - \\
\hline Alternative Mortgage Product (AMP) & 0.15 & 0.00 & - & 0.15 & 0.00 & - \\
\hline Adjustable Rate Mortgage (ARM) & 0.44 & 0.00 & - & 0.32 & 0.00 & - \\
\hline \multicolumn{7}{|l|}{ Financial Circumstances } \\
\hline Recent income loss $(=1)$ & 0.10 & 0.17 & 0.004 & 0.17 & 0.20 & 0.573 \\
\hline Credit constrained $(=1)$ & 0.04 & 0.15 & 0.000 & 0.05 & 0.12 & 0.003 \\
\hline \multicolumn{7}{|l|}{ Financial Literacy } \\
\hline Education leaving age (years) & 19.60 & 19.77 & 0.419 & 18.20 & 17.00 & 0.000 \\
\hline Math level in school (1-5) & 3.69 & 3.71 & 0.771 & 3.52 & 3.35 & 0.116 \\
\hline Financial literacy score $(0-4)$ & 2.21 & 1.75 & 0.000 & 2.07 & 1.53 & 0.000 \\
\hline \multicolumn{7}{|l|}{ Correctly answered questions: } \\
\hline Q1: Interest over time & 0.77 & 0.61 & 0.000 & 0.73 & 0.62 & 0.019 \\
\hline Q2: Simple interest & 0.63 & 0.53 & 0.013 & 0.57 & 0.40 & 0.001 \\
\hline Q3: Compound interest & 0.47 & 0.36 & 0.004 & 0.46 & 0.29 & 0.001 \\
\hline Q4: Time to repay & 0.34 & 0.26 & 0.026 & 0.31 & 0.21 & 0.038 \\
\hline \multicolumn{7}{|l|}{ Behavioral Characteristics } \\
\hline Patience $(0-10)^{\mathrm{a}}$ & 5.15 & 5.76 & 0.003 & 5.98 & 6.08 & 0.696 \\
\hline Risk attitude $(0-10)^{\mathrm{a}}$ & 4.27 & 4.72 & 0.015 & 4.34 & 4.33 & 0.965 \\
\hline Present biased $(=1)^{b}$ & 0.13 & 0.21 & 0.012 & 0.10 & 0.16 & 0.086 \\
\hline Observations & 339 & 299 & 638 & 440 & 127 & 567 \\
\hline
\end{tabular}

Note: Table shows summary statistics split by young households (18-44) and old households (45 and above) as well as homeowners and renters. Columns 3 and 6 report p-values from t-tests for the equivalence of means across age groups and homeownership groups 
Table 5: Homeowner IV Probit Models

\begin{tabular}{|c|c|c|c|c|c|c|}
\hline & \multicolumn{2}{|c|}{$\begin{array}{c}\text { (1) } \\
\text { All } \\
\text { Households }\end{array}$} & \multicolumn{2}{|c|}{$\begin{array}{c}\text { (2) } \\
\text { Young } \\
\text { Households }\end{array}$} & \multicolumn{2}{|c|}{$\begin{array}{c}\text { (3) } \\
\text { Old } \\
\text { Households }\end{array}$} \\
\hline & $\beta / \mathrm{SE}$ & Margin & $\beta / \mathrm{SE}$ & Margin & $\beta / \mathrm{SE}$ & Margin \\
\hline \multicolumn{7}{|l|}{ Financial Literacy } \\
\hline Financial literacy score $(0-4)$ & $\begin{array}{c}0.168^{*} \\
(0.097)\end{array}$ & $0.022^{*}$ & $\begin{array}{l}0.371^{* * *} \\
(0.106)\end{array}$ & $0.027^{* * *}$ & $\begin{array}{r}-0.001 \\
(0.155)\end{array}$ & -0.026 \\
\hline \multicolumn{7}{|l|}{ Behavioural Characteristics } \\
\hline Patience $(0-10)$ & $\begin{array}{c}-0.018 \\
(0.019)\end{array}$ & -0.002 & $\begin{array}{r}-0.039 \\
(0.025)\end{array}$ & -0.003 & $\begin{array}{c}-0.001 \\
(0.027)\end{array}$ & -0.000 \\
\hline Present biased $(=1)$ & $\begin{array}{r}-0.257^{*} \\
(0.132)\end{array}$ & $-0.054^{*}$ & $\begin{array}{c}-0.363^{* *} \\
(0.178)\end{array}$ & $-0.087^{* *}$ & $\begin{array}{r}-0.181 \\
(0.198)\end{array}$ & -0.038 \\
\hline Risk attitude $(0-10)$ & $\begin{array}{r}-0.017 \\
(0.020)\end{array}$ & -0.003 & $\begin{array}{c}-0.028 \\
(0.028)\end{array}$ & -0.001 & $\begin{array}{c}-0.017 \\
(0.029)\end{array}$ & -0.004 \\
\hline \multicolumn{7}{|l|}{ Demographics } \\
\hline Male (= 1) & $\begin{array}{r}-0.111 \\
(0.111)\end{array}$ & -0.054 & $\begin{array}{c}0.082 \\
(0.151)\end{array}$ & -0.056 & $\begin{array}{r}-0.254^{*} \\
(0.149)\end{array}$ & $-0.065^{*}$ \\
\hline Education leaving age (years) & $\begin{array}{l}0.051^{* *} \\
(0.021)\end{array}$ & $0.008^{* *}$ & $\begin{array}{r}-0.003 \\
(0.029)\end{array}$ & -0.007 & $\begin{array}{l}0.086^{* * *} \\
(0.032)\end{array}$ & $0.018^{* * *}$ \\
\hline \multicolumn{7}{|l|}{ Household Finances } \\
\hline Household income ( $£ 10,000 \mathrm{~s})$ & $\begin{array}{l}0.291^{* * *} \\
(0.059)\end{array}$ & $0.057^{* * *}$ & $\begin{array}{l}0.297^{* * *} \\
(0.072)\end{array}$ & $0.056^{* * *}$ & $\begin{array}{l}0.320^{* * *} \\
(0.101)\end{array}$ & $0.068^{* * *}$ \\
\hline Household income $^{2}$ & $\begin{array}{c}-0.010^{* * *} \\
(0.004)\end{array}$ & $-0.002^{* * *}$ & $\begin{array}{c}-0.010^{* *} \\
(0.005)\end{array}$ & $-0.002^{* *}$ & $\begin{array}{c}-0.011 \\
(0.007)\end{array}$ & -0.002 \\
\hline \multicolumn{7}{|l|}{ Financial Circumstances } \\
\hline Recent income loss $(=1)$ & $\begin{array}{r}-0.228^{*} \\
(0.127)\end{array}$ & $-0.051^{*}$ & $\begin{array}{c}-0.417^{* *} \\
(0.190)\end{array}$ & $-0.101^{* *}$ & $\begin{array}{c}0.017 \\
(0.175)\end{array}$ & 0.003 \\
\hline Credit constrained $(=1)$ & $\begin{array}{c}-0.427^{* *} \\
(0.176)\end{array}$ & $-0.099^{* *}$ & $\begin{array}{r}-0.293 \\
(0.230)\end{array}$ & -0.096 & $\begin{array}{c}-0.645^{* *} \\
(0.268)\end{array}$ & $-0.139^{* *}$ \\
\hline \multicolumn{7}{|l|}{ Regional Housing Market Characteristics } \\
\hline 5-year $\sigma$ of mean house prices & $\begin{array}{c}-0.120^{* * *} \\
(0.023)\end{array}$ & $-0.028^{* * *}$ & $\begin{array}{c}-0.249^{* * *} \\
(0.064)\end{array}$ & $-0.058^{* * *}$ & $\begin{array}{c}-0.077^{* * *} \\
(0.027)\end{array}$ & $-0.018^{* * *}$ \\
\hline 5-year growth of mean house prices & $\begin{array}{l}4.040^{* * *} \\
(0.400)\end{array}$ & $0.895^{* * *}$ & $\begin{array}{l}5.321^{* * *} \\
(0.713)\end{array}$ & $1.232^{* * *}$ & $\begin{array}{l}2.643^{* * *} \\
(0.565)\end{array}$ & $0.596^{* * *}$ \\
\hline Home ownership ratio in 2011 & $\begin{array}{c}-0.001 \\
(0.008)\end{array}$ & -0.002 & $\begin{array}{c}0.005 \\
(0.012)\end{array}$ & -0.001 & $\begin{array}{c}-0.011 \\
(0.012)\end{array}$ & -0.003 \\
\hline House price to average income ratio & $\begin{array}{c}-0.680^{* * *} \\
(0.160)\end{array}$ & $-0.159^{* * *}$ & $\begin{array}{c}-0.550^{* * *} \\
(0.218)\end{array}$ & $-0.152^{* * *}$ & $\begin{array}{c}-0.661^{* * *} \\
(0.234)\end{array}$ & $-0.149^{* * *}$ \\
\hline Rental yield & $\begin{array}{c}0.115 \\
(0.217)\end{array}$ & 0.030 & $\begin{array}{c}0.403 \\
(0.281)\end{array}$ & 0.107 & $\begin{array}{c}-0.035 \\
(0.326)\end{array}$ & -0.006 \\
\hline Observations & 1205 & & 638 & & 567 & \\
\hline F-Statistic of first stage & 20.309 & & 14.330 & & 10.136 & \\
\hline LR chi2 / F & 359.494 & & 207.045 & & 96.541 & \\
\hline Prob $>$ chi2 $/ \mathrm{F}$ & 0.000 & & 0.000 & & 0.000 & \\
\hline Wald test of exogeneity & 0.013 & & 0.000 & & 0.484 & \\
\hline Baseline predicted probability & 0.647 & & 0.513 & & 0.801 & \\
\hline
\end{tabular}

Note: Table shows results from instrumental variable probit estimates and average marginal effects. ${ }^{*} \mathrm{p}<0.1,{ }^{* *} \mathrm{p}<$ $0.05,{ }^{* * *} \mathrm{p}<0.01$. Standard errors in parentheses. Sample includes all survey respondents (1), only young households aged 18-44 (2) and old households aged 45 and above (3), respectively. The dependent variable for all models is a $1 / 0$ dummy for which a value of 1 denotes the individual is an homeowner and a value of 0 denotes the individual is a renter. First stage regression results are shown in Table A2. Additional controls not shown: 1/0 dummies for marital status, dependent children, (spouse) employment status and age (in Column 1 only). 
Table 6: Homeowner IV Probit Model excluding “Don’t knows”

\begin{tabular}{|c|c|c|c|c|c|c|}
\hline & \multicolumn{2}{|c|}{$\begin{array}{c}\text { (1) } \\
\text { All } \\
\text { Households }\end{array}$} & \multicolumn{2}{|c|}{$\begin{array}{c}\text { (2) } \\
\text { Young } \\
\text { Households }\end{array}$} & \multicolumn{2}{|c|}{$\begin{array}{c}\text { (3) } \\
\text { Old } \\
\text { Households }\end{array}$} \\
\hline & $\beta / \mathrm{SE}$ & Margin & $\beta / \mathrm{SE}$ & Margin & $\beta / \mathrm{SE}$ & Margin \\
\hline \multicolumn{7}{|l|}{ Financial Literacy } \\
\hline Financial literacy score $(0-4)$ & $\begin{array}{c}0.239 \\
(0.164)\end{array}$ & 0.028 & $\begin{array}{l}0.589^{* * *} \\
(0.134)\end{array}$ & $0.035^{* * *}$ & $\begin{array}{r}-0.136 \\
(0.294)\end{array}$ & -0.032 \\
\hline \multicolumn{7}{|l|}{ Behavioural Characteristics } \\
\hline Patience $(0-10)$ & $\begin{array}{c}-0.021 \\
(0.023)\end{array}$ & -0.001 & $\begin{array}{r}-0.040 \\
(0.028)\end{array}$ & -0.001 & $\begin{array}{c}-0.003 \\
(0.034)\end{array}$ & -0.001 \\
\hline Present biased $(=1)$ & $\begin{array}{c}-0.395^{* * *} \\
(0.155)\end{array}$ & $-0.076^{* * *}$ & $\begin{array}{r}-0.298 \\
(0.196)\end{array}$ & -0.070 & $\begin{array}{r}-0.436^{*} \\
(0.238)\end{array}$ & $-0.086^{*}$ \\
\hline Risk attitude $(0-10)$ & $\begin{array}{c}-0.036 \\
(0.024)\end{array}$ & -0.005 & $\begin{array}{c}-0.063^{* *} \\
(0.031)\end{array}$ & $-0.005^{* *}$ & $\begin{array}{r}-0.051 \\
(0.036)\end{array}$ & -0.010 \\
\hline Observations & 926 & & 490 & & 436 & \\
\hline F-statistic of first stage & 10.780 & & 8.470 & & 7.220 & \\
\hline LR chi2 / F & 286.198 & & 206.184 & & 75.279 & \\
\hline Prob $>$ chi $2 / \mathrm{F}$ & 0.000 & & 0.000 & & 0.000 & \\
\hline Wald test of exogeneity & 0.039 & & 0.000 & & 0.938 & \\
\hline Baseline predicted probability & 0.646 & & 0.515 & & 0.795 & \\
\hline
\end{tabular}

Note: Table shows results from instrumental variable probit estimates and average marginal effects. ${ }^{*} \mathrm{p}<0.1$, ${ }^{* *} \mathrm{p}<0.05,{ }^{* * *} \mathrm{p}<0.01$. Standard errors in parentheses. Sample excludes respondents who answered "don't know" to the very first literacy question and/or those who answered "don't know" to three or more questions (279 observations in total in Column 1). The dependent variable for all models is a 1/0 dummy for which a value of 1 denotes the individual is an homeowner and a value of 0 denotes the individual is a renter. Young households (2) are aged 18-44, old households (3) are aged 45 and above. Additional covariates as in Table 5. 
Table 7: Instrumental Variable Model with Selectivity Correction for Mortgage Borrowing of Young Households (18-44)

\begin{tabular}{|c|c|c|c|c|}
\hline & \multicolumn{2}{|c|}{$\begin{array}{c}(1) \\
\text { Loan-to-Value } \\
\text { Ratio }\end{array}$} & \multicolumn{2}{|c|}{$\begin{array}{c}(2) \\
\text { Loan-to-Income } \\
\text { Ratio }\end{array}$} \\
\hline & $\beta / \mathrm{SE}$ & Margin & $\beta / \mathrm{SE}$ & Margin \\
\hline Inverse Mills Ratio & $\begin{array}{c}-5.887^{* * *} \\
(0.854)\end{array}$ & $-0.443^{* * *}$ & $\begin{array}{c}-4.974^{* * *} \\
(1.634)\end{array}$ & $-0.186^{* * *}$ \\
\hline \multicolumn{5}{|l|}{ Financial Literacy } \\
\hline Financial literacy score $(0-4)$ & $\begin{array}{c}-0.955^{* * *} \\
(0.212)\end{array}$ & $-0.016^{* * *}$ & $\begin{array}{c}-0.797^{* *} \\
(0.361)\end{array}$ & $-0.011^{* *}$ \\
\hline \multicolumn{5}{|l|}{ Behavioural Characteristics } \\
\hline Patience $(0-10)$ & $\begin{array}{c}0.059^{* *} \\
(0.025)\end{array}$ & $0.001^{* *}$ & $\begin{array}{c}0.045 \\
(0.034)\end{array}$ & -0.002 \\
\hline Present biased $(=1)$ & $\begin{array}{c}0.029 \\
(0.145)\end{array}$ & -0.024 & $\begin{array}{c}0.026 \\
(0.158)\end{array}$ & -0.017 \\
\hline Risk attitude $(0-10)$ & $\begin{array}{c}0.066 \\
(0.049)\end{array}$ & -0.013 & $\begin{array}{c}0.033 \\
(0.071)\end{array}$ & -0.018 \\
\hline \multicolumn{5}{|l|}{ Demographics } \\
\hline Male $(=1)$ & $\begin{array}{l}0.786^{* * *} \\
(0.183)\end{array}$ & $0.021^{* * *}$ & $\begin{array}{c}0.580^{*} \\
(0.332)\end{array}$ & $-0.029^{*}$ \\
\hline Education leaving age (years) & $\begin{array}{l}0.257^{* * *} \\
(0.079)\end{array}$ & $0.010^{* * *}$ & $\begin{array}{c}0.188 \\
(0.127)\end{array}$ & -0.008 \\
\hline \multicolumn{5}{|l|}{ Financial Circumstances } \\
\hline Recent income loss $(=1)$ & $\begin{array}{l}0.598^{* * *} \\
(0.202)\end{array}$ & $0.018^{* * *}$ & $\begin{array}{c}0.562^{* *} \\
(0.254)\end{array}$ & $0.019^{* *}$ \\
\hline Credit constrained $(=1)$ & $\begin{array}{l}3.062^{* * *} \\
(0.526)\end{array}$ & $0.189^{* * *}$ & $\begin{array}{c}2.421^{* *} \\
(1.024)\end{array}$ & $0.014^{* *}$ \\
\hline Observations & 638 & & 638 & \\
\hline F-statistic of first stage & 24.660 & & 24.660 & \\
\hline LR chi2 & 250.283 & & 130.941 & \\
\hline Prob > chi2 & 0.000 & & 0.000 & \\
\hline Wald test of exogeneity & 0.070 & & 0.166 & \\
\hline Baseline predicted probability & 0.213 & & 0.155 & \\
\hline
\end{tabular}

Note: Table shows results from instrumental variable probit models with selectivity correction (the equivalent model without selectivity correction is shown in Table A4). ${ }^{*} \mathrm{p}<0.1,{ }^{* *} \mathrm{p}<0.05,{ }^{* * *} \mathrm{p}<0.01$. Average marginal effects reported, standard errors in parentheses. As in previous models, financial literacy is instrumented by the math level in school. The selection model is whether the individual holds a mortgage or not, instrumented by the local house price to income ratio (the selection correction term is shown by the inverse mills ratio). The dependent variable in Column 1 is a $1 / 0$ dummy variable indicating whether the loan-to-value ratio of the household is larger than the 75th percentile in the distribution. Likewise, the dependent variable in Column 2 is a $1 / 0$ dummy variable indicating whether the loan-to-income ratio of the household is larger than the 75th percentile in the distribution. Sample includes only young households. Additional controls not shown: 1/0 dummies for marital status, dependent children and (spouse) employment status. 
Table 8: Instrumental Variable Model with Selectivity Correction for Mortgage Characteristics of Young Households (18-44)

\begin{tabular}{|c|c|c|c|c|c|c|}
\hline & \multicolumn{2}{|c|}{$\begin{array}{l}(1) \\
\text { Refinanced within } \\
\text { past } 3 \text { years }\end{array}$} & \multicolumn{2}{|c|}{$\begin{array}{l}\qquad(2) \\
\text { Alternative Mortgage } \\
\text { Product }\end{array}$} & \multicolumn{2}{|c|}{$\begin{array}{c}(3) \\
\text { Adjustable Rate } \\
\text { Mortgage }\end{array}$} \\
\hline & $\beta / \mathrm{SE}$ & Margin & $\beta / \mathrm{SE}$ & Margin & $\beta / \mathrm{SE}$ & Margin \\
\hline Inverse Mills Ratio & $\begin{array}{c}-2.684^{* * *} \\
(0.608)\end{array}$ & $-0.427^{* * *}$ & $\begin{array}{c}-2.509^{* * *} \\
(0.875)\end{array}$ & $-0.260^{* * *}$ & $\begin{array}{l}12.599^{*} \\
(7.061)\end{array}$ & $-0.147^{*}$ \\
\hline \multicolumn{7}{|l|}{ Financial Literacy } \\
\hline Financial literacy score $(0-4)$ & $\begin{array}{c}-0.353^{* *} \\
(0.164)\end{array}$ & $-0.015^{\star *}$ & $\begin{array}{c}-0.503^{* *} \\
(0.218)\end{array}$ & $-0.042^{* *}$ & $\begin{array}{l}1.764^{* *} \\
(0.840)\end{array}$ & $0.020^{* *}$ \\
\hline \multicolumn{7}{|l|}{ Behavioural Characteristics } \\
\hline Patience $(0-10)$ & $\begin{array}{c}0.036 \\
(0.028)\end{array}$ & 0.008 & $\begin{array}{c}0.026 \\
(0.036)\end{array}$ & 0.003 & $\begin{array}{r}-0.011 \\
(0.053)\end{array}$ & -0.017 \\
\hline Present biased $(=1)$ & $\begin{array}{r}-0.154 \\
(0.189)\end{array}$ & -0.032 & $\begin{array}{l}0.601^{* * *} \\
(0.206)\end{array}$ & $0.073^{* * *}$ & $\begin{array}{c}0.131 \\
(0.182)\end{array}$ & -0.010 \\
\hline Risk attitude $(0-10)$ & $\begin{array}{l}0.138^{* * *} \\
(0.035)\end{array}$ & $0.027^{* * *}$ & $\begin{array}{c}0.033 \\
(0.044)\end{array}$ & 0.003 & $\begin{array}{r}-0.034 \\
(0.046)\end{array}$ & -0.018 \\
\hline \multicolumn{7}{|l|}{ Demographics } \\
\hline Male $(=1)$ & $\begin{array}{c}0.142 \\
(0.205)\end{array}$ & -0.021 & $\begin{array}{c}0.324 \\
(0.271)\end{array}$ & 0.022 & $\begin{array}{c}-0.073 \\
(0.170)\end{array}$ & 0.033 \\
\hline Education leaving age (years) & $\begin{array}{c}0.056^{*} \\
(0.029)\end{array}$ & $0.010^{*}$ & $\begin{array}{r}-0.019 \\
(0.038)\end{array}$ & -0.003 & $\begin{array}{r}-0.030 \\
(0.023)\end{array}$ & -0.009 \\
\hline \multicolumn{7}{|l|}{ Household Finances } \\
\hline Household income $(£ 10,000 s)$ & $\begin{array}{c}-0.219^{* *} \\
(0.112)\end{array}$ & $-0.031^{* *}$ & $\begin{array}{c}-0.212 \\
(0.147)\end{array}$ & -0.021 & $\begin{array}{c}0.038 \\
(0.124)\end{array}$ & 0.039 \\
\hline Household income ${ }^{2}$ & $\begin{array}{c}0.006 \\
(0.005)\end{array}$ & 0.001 & $\begin{array}{c}0.009 \\
(0.006)\end{array}$ & 0.001 & $\begin{array}{r}-0.002 \\
(0.004)\end{array}$ & -0.001 \\
\hline \multicolumn{7}{|l|}{ Financial Circumstances } \\
\hline Recent income loss $(=1)$ & $\begin{array}{c}0.007 \\
(0.215)\end{array}$ & -0.003 & $\begin{array}{c}0.563^{* *} \\
(0.229)\end{array}$ & $0.067^{* *}$ & $\begin{array}{c}0.434^{* *} \\
(0.200)\end{array}$ & $0.112^{* *}$ \\
\hline Credit constrained $(=1)$ & $\begin{array}{l}1.167^{* * *} \\
(0.384)\end{array}$ & $0.167^{* * *}$ & $\begin{array}{l}1.010^{* *} \\
(0.513)\end{array}$ & $0.097^{* *}$ & $\begin{array}{c}-0.226 \\
(0.213)\end{array}$ & -0.004 \\
\hline Observations & 638 & & 638 & & 638 & \\
\hline F-statistic of first stage & 25.740 & & 25.740 & & 25.740 & \\
\hline LR chi2 & 54.590 & & 47.357 & & 307.769 & \\
\hline Prob > chi2 & 0.000 & & 0.000 & & 0.000 & \\
\hline Wald test of exogeneity & 0.134 & & 0.526 & & 0.274 & \\
\hline Baseline predicted probability & 0.134 & & 0.072 & & 0.224 & \\
\hline
\end{tabular}

Note: Table shows results from instrumental variable probit models with selectivity correction (the equivalent model without selectivity correction is shown in Table A5). ${ }^{*} \mathrm{p}<0.1,{ }^{* *} \mathrm{p}<0.05,{ }^{* * *} \mathrm{p}<0.01$. Average marginal effects reported, standard errors in parentheses. Financial literacy is instrumented by the math level in school. The selection model is whether the individual holds a mortgage or not, instrumented by the local house price to income ratio (the selection correction term is shown by the inverse mills ratio). The dependent variables are 1/0 dummy variables for, respectively: Column 1, whether the individual refinanced the mortgage within the last 3 years $(=1)$; Column 2, whether the individual holds an alternative mortgage product $(=1)$ or a standard repayment mortgage; Column 3, whether the individual holds an adjustable rate mortgage $(=0)$ or a fixed rate mortgage. Sample includes only young households. Additional controls not shown: 1/0 dummies for marital status, dependent children and (spouse) employment status. 
Appendix Tables 
Table A1: Regional Housing Market Characteristics

\begin{tabular}{lccc}
\hline & $\begin{array}{c}(1) \\
\text { Full } \\
\text { Sample }\end{array}$ & Homeowner & Renter \\
\hline 5-year $\sigma$ of mean house prices & $\begin{array}{c}13800 \\
(8400)\end{array}$ & $\begin{array}{c}12500 \\
(8000)\end{array}$ & $\begin{array}{c}(36000 \\
(9300)\end{array}$ \\
5-year growth of mean house prices & 0.17 & 0.24 & 0.04 \\
Home ownership ratio in 2011 & 64.53 & 64.83 & 63.97 \\
House price to average income ratio & 3.96 & 3.94 & 4.01 \\
Rental yield & 6.05 & 6.06 & 6.04 \\
\hline Observations & 1205 & 779 & 426 \\
\hline
\end{tabular}

Note: Variables are calculated as follows: 5-year growth of mean house prices and standard deviation of mean house prices are calculated from all sales within the postcode district in which the household is located using England and Wales Land Registry sales data. Home ownership ratio in 2011 is calculated at the regional level from UK Census data. This measures the proportion of households in each region who live in a house which they own, either with or without a mortgage. House price to average income ratio in the region in which the household is resident is calculated using house price data taken from the UK's official house price sales index and income data from the UK Office for National Statistics. The simple gross rental yield in the region of residence is calculated by the financial consulting agency BM Solutions. The rental yield is average annual rental income divided by average property prices. Mean values reported, medians in parentheses for financial variables. 
Table A2: IV Probit Models First Stage

\begin{tabular}{|c|c|c|c|}
\hline & $\begin{array}{c}(1) \\
\text { All } \\
\text { Households } \\
\beta \text { / SE }\end{array}$ & $\begin{array}{c}(2) \\
\text { Young } \\
\text { Households } \\
\beta / \mathrm{SE}\end{array}$ & $\begin{array}{c}\text { (3) } \\
\text { Old } \\
\text { Households } \\
\beta \text { / SE }\end{array}$ \\
\hline \multicolumn{4}{|l|}{ Instrument } \\
\hline Math level in school $(1-5)$ & $\begin{array}{l}0.466^{* * *} \\
(0.035)\end{array}$ & $\begin{array}{l}0.494^{* * *} \\
(0.051)\end{array}$ & $\begin{array}{l}0.433^{* * *} \\
(0.050)\end{array}$ \\
\hline \multicolumn{4}{|l|}{ Behavioral Characteristics } \\
\hline Patience $(0-10)$ & $\begin{array}{c}-0.032^{* *} \\
(0.014)\end{array}$ & $\begin{array}{c}-0.053^{* * *} \\
(0.018)\end{array}$ & $\begin{array}{c}0.004 \\
(0.020)\end{array}$ \\
\hline Present biased $(=1)$ & $\begin{array}{c}-0.079 \\
(0.100)\end{array}$ & $\begin{array}{c}-0.006 \\
(0.130)\end{array}$ & $\begin{array}{r}-0.143 \\
(0.162)\end{array}$ \\
\hline Risk attitude $(0-10)$ & $\begin{array}{r}-0.021 \\
(0.015)\end{array}$ & $\begin{array}{c}-0.052^{* *} \\
(0.021)\end{array}$ & $\begin{array}{c}0.015 \\
(0.022)\end{array}$ \\
\hline \multicolumn{4}{|l|}{ Demographics } \\
\hline Male $(=1)$ & $\begin{array}{l}0.484^{* * *} \\
(0.070)\end{array}$ & $\begin{array}{l}0.653^{* * *} \\
(0.096)\end{array}$ & $\begin{array}{l}0.275^{* * *} \\
(0.104)\end{array}$ \\
\hline Education leaving age (years) & $\begin{array}{l}0.065^{* * *} \\
(0.014)\end{array}$ & $\begin{array}{l}0.053^{* * *} \\
(0.020)\end{array}$ & $\begin{array}{l}0.068^{* * *} \\
(0.021)\end{array}$ \\
\hline \multicolumn{4}{|l|}{ Household Finances } \\
\hline Household income $(£ 10,000 \mathrm{~s})$ & $\begin{array}{l}0.155^{* * *} \\
(0.040)\end{array}$ & $\begin{array}{c}0.132^{* *} \\
(0.054)\end{array}$ & $\begin{array}{l}0.186^{* * *} \\
(0.060)\end{array}$ \\
\hline Household income $^{2}$ & $\begin{array}{c}-0.007^{* * *} \\
(0.002)\end{array}$ & $\begin{array}{c}-0.007^{* *} \\
(0.003)\end{array}$ & $\begin{array}{c}-0.007^{* *} \\
(0.004)\end{array}$ \\
\hline \multicolumn{4}{|l|}{ Financial Circumstances } \\
\hline Recent income loss $(=1)$ & $\begin{array}{c}-0.010 \\
(0.096)\end{array}$ & $\begin{array}{c}0.003 \\
(0.140)\end{array}$ & $\begin{array}{c}0.027 \\
(0.134)\end{array}$ \\
\hline Credit constrained $(=1)$ & $\begin{array}{c}0.039 \\
(0.131)\end{array}$ & $\begin{array}{c}0.220 \\
(0.167)\end{array}$ & $\begin{array}{r}-0.334 \\
(0.214)\end{array}$ \\
\hline \multicolumn{4}{|l|}{ Regional Housing Market Characteristics } \\
\hline 5-year $\sigma$ of mean house prices & $\begin{array}{c}0.015 \\
(0.020)\end{array}$ & $\begin{array}{r}-0.014 \\
(0.032)\end{array}$ & $\begin{array}{c}0.032 \\
(0.026)\end{array}$ \\
\hline 5-year growth of mean house prices & $\begin{array}{l}0.377^{* * *} \\
(0.127)\end{array}$ & $\begin{array}{l}0.417^{* * *} \\
(0.156)\end{array}$ & $\begin{array}{c}0.304 \\
(0.225)\end{array}$ \\
\hline Home ownership ratio in 2011 & $\begin{array}{l}0.021^{* * *} \\
(0.006)\end{array}$ & $\begin{array}{l}0.017^{* *} \\
(0.008)\end{array}$ & $\begin{array}{l}0.019^{* *} \\
(0.009)\end{array}$ \\
\hline House price to average income ratio & $\begin{array}{c}0.078 \\
(0.112)\end{array}$ & $\begin{array}{c}0.171 \\
(0.156)\end{array}$ & $\begin{array}{r}-0.065 \\
(0.167)\end{array}$ \\
\hline Rental yield & $\begin{array}{r}-0.071 \\
(0.160)\end{array}$ & $\begin{array}{c}-0.084 \\
(0.219)\end{array}$ & $\begin{array}{r}-0.072 \\
(0.235)\end{array}$ \\
\hline Observations & 1205 & 638 & 567 \\
\hline$R^{2}$ & 0.274 & 0.306 & 0.260 \\
\hline F-statistic & 20.309 & 14.330 & 10.136 \\
\hline Prob $>$ F & 0.000 & 0.000 & 0.000 \\
\hline Baseline predicted probability & 1.973 & 1.879 & 2.099 \\
\hline
\end{tabular}

Note: Table shows the first stage results of the instrumental variable probit models in Table 5. ${ }^{*} \mathrm{p}<0.1,{ }^{* *} \mathrm{p}<0.05,{ }^{* * *} \mathrm{p}<0.01$. Robust standard errors in parentheses. Sample includes all survey respondents. The dependent variable for all models is the financial literacy score, ranging 0-4. Young households (2) are aged 18-44, old households (3) are aged 45 and above. Additional controls not shown: 1/0 dummies for marital status, dependent children, (spouse) employment status and age in Column 1. 
Table A3: Homeowner IV Probit Model excluding Homeowners without a Mortgage

\begin{tabular}{|c|c|c|c|c|c|c|}
\hline & \multicolumn{2}{|c|}{$\begin{array}{c}(1) \\
\text { All } \\
\text { Households }\end{array}$} & \multicolumn{2}{|c|}{$\begin{array}{c}\text { (2) } \\
\text { Young } \\
\text { Households }\end{array}$} & \multicolumn{2}{|c|}{$\begin{array}{c}\text { (3) } \\
\text { Old } \\
\text { Households }\end{array}$} \\
\hline & $\beta / \mathrm{SE}$ & Margin & $\beta / \mathrm{SE}$ & Margin & $\beta / \mathrm{SE}$ & Margin \\
\hline \multicolumn{7}{|l|}{ Financial Literacy } \\
\hline Financial literacy score $(0-4)$ & $\begin{array}{c}0.191^{*} \\
(0.109)\end{array}$ & $0.017^{*}$ & $\begin{array}{l}0.369^{* * *} \\
(0.110)\end{array}$ & $0.031^{* * *}$ & $\begin{array}{r}-0.134 \\
(0.198)\end{array}$ & -0.016 \\
\hline \multicolumn{7}{|l|}{ Behavioural Characteristics } \\
\hline Patience $(0-10)$ & $\begin{array}{c}-0.034 \\
(0.022)\end{array}$ & -0.004 & $\begin{array}{r}-0.039 \\
(0.028)\end{array}$ & -0.001 & $\begin{array}{c}-0.026 \\
(0.036)\end{array}$ & -0.005 \\
\hline Present biased $(=1)$ & $\begin{array}{r}-0.166 \\
(0.147)\end{array}$ & -0.033 & $\begin{array}{c}-0.268 \\
(0.183)\end{array}$ & -0.061 & $\begin{array}{r}-0.160 \\
(0.235)\end{array}$ & -0.034 \\
\hline Risk attitude $(0-10)$ & $\begin{array}{r}-0.037 \\
(0.025)\end{array}$ & -0.006 & $\begin{array}{r}-0.042 \\
(0.031)\end{array}$ & -0.004 & $\begin{array}{r}-0.069^{*} \\
(0.038)\end{array}$ & $-0.015^{*}$ \\
\hline Observations & 993 & & 607 & & 386 & \\
\hline F-statistic of first stage & 14.500 & & 11.600 & & 8.730 & \\
\hline LR chi2 / F & 291.501 & & 210.640 & & 104.613 & \\
\hline Prob $>$ chi $2 / \mathrm{F}$ & 0.000 & & 0.000 & & 0.000 & \\
\hline Wald test of exogeneity & 0.025 & & 0.000 & & 0.330 & \\
\hline Baseline predicted probability & 0.566 & & 0.473 & & 0.676 & \\
\hline
\end{tabular}

Note: Table shows results from instrumental variable probit estimates and average marginal effects. ${ }^{*} \mathrm{p}<$ $0.1,{ }^{* *} \mathrm{p}<0.05,{ }^{* * *} \mathrm{p}<0.01$. Standard errors in parentheses. Sample excludes all homeowners who own their properties without a mortgage. The dependent variable for all models is a $1 / 0$ dummy for which a value of 1 denotes the individual is an homeowner and a value of 0 denotes the individual is a renter. Young households (2) are aged 18-44, old households (3) are aged 45 and above. Additional covariates as in Table 5. 
Table A4: Instrumental Variable Model (without Selectivity Correction) for Mortgage Borrowing of Young Households (18-44)

\begin{tabular}{|c|c|c|c|c|}
\hline & \multicolumn{2}{|c|}{$\begin{array}{c}(1) \\
\text { Loan-to-Value } \\
\text { Ratio }\end{array}$} & \multicolumn{2}{|c|}{$\begin{array}{c}(2) \\
\text { Loan-to-Income } \\
\text { Ratio }\end{array}$} \\
\hline & $\beta / \mathrm{SE}$ & Margin & $\beta / \mathrm{SE}$ & Margin \\
\hline \multicolumn{5}{|l|}{ Financial Literacy } \\
\hline Financial literacy score $(0-4)$ & $\begin{array}{c}-0.752^{* * *} \\
(0.135)\end{array}$ & $-0.011^{* * *}$ & $\begin{array}{c}-0.652^{* * *} \\
(0.214)\end{array}$ & $-0.024^{* * *}$ \\
\hline \multicolumn{5}{|l|}{ Behavioural Characteristics } \\
\hline Patience $(0-10)$ & $\begin{array}{c}-0.069^{* * *} \\
(0.026)\end{array}$ & $-0.006^{* * *}$ & $\begin{array}{c}-0.065^{* *} \\
(0.029)\end{array}$ & $-0.004^{* *}$ \\
\hline Present biased $(=1)$ & $\begin{array}{r}-0.005 \\
(0.188)\end{array}$ & -0.041 & $\begin{array}{c}0.046 \\
(0.194)\end{array}$ & -0.002 \\
\hline Risk attitude $(0-10)$ & $\begin{array}{c}-0.104^{* * *} \\
(0.036)\end{array}$ & $-0.038^{* * *}$ & $\begin{array}{c}-0.110^{* * *} \\
(0.037)\end{array}$ & $-0.034^{* * *}$ \\
\hline \multicolumn{5}{|l|}{ Demographics } \\
\hline Male $(=1)$ & $\begin{array}{l}0.538^{* * *} \\
(0.149)\end{array}$ & $0.024^{* * *}$ & $\begin{array}{c}0.394^{*} \\
(0.211)\end{array}$ & $-0.045^{*}$ \\
\hline Education leaving age (years) & $\begin{array}{l}0.462^{* * *} \\
(0.090)\end{array}$ & $0.057^{* * *}$ & $\begin{array}{l}0.376^{* * *} \\
(0.135)\end{array}$ & $0.009^{* * *}$ \\
\hline \multicolumn{5}{|l|}{ Financial Circumstances } \\
\hline Recent income loss $(=1)$ & $\begin{array}{r}-0.048 \\
(0.212)\end{array}$ & 0.003 & $\begin{array}{r}-0.019 \\
(0.218)\end{array}$ & 0.017 \\
\hline Credit constrained $(=1)$ & $\begin{array}{c}0.401 \\
(0.330)\end{array}$ & 0.203 & $\begin{array}{c}0.204 \\
(0.314)\end{array}$ & 0.053 \\
\hline Observations & 308 & & 308 & \\
\hline F-statistic of first stage & 12.210 & & 12.460 & \\
\hline LR chi2 & 108.088 & & 97.565 & \\
\hline Prob > chi2 & 0.000 & & 0.000 & \\
\hline Wald test of exogeneity & 0.036 & & 0.079 & \\
\hline Baseline predicted probability & 0.414 & & 0.339 & \\
\hline
\end{tabular}

Note: Table shows results from instrumental variable probit models (the equivalent model with selectivity correction is shown in Table 7). ${ }^{*} \mathrm{p}<0.1,{ }^{* *} \mathrm{p}<0.05,{ }^{* * *} \mathrm{p}<0.01$. Average marginal effects reported, standard errors in parentheses. As in previous models, financial literacy is instrumented by the math level in school. The dependent variable in Column 1 is a $1 / 0$ dummy variable indicating whether the loan-to-value ratio of the household is larger than the 75 th percentile in the distribution. Likewise, the dependent variable in Column 2 is a $1 / 0$ dummy variable indicating whether the loan-to-income ratio of the household is larger than the 75th percentile in the distribution. Sample includes only young households. Additional controls not shown: 1/0 dummies for marital status, dependent children and (spouse) employment status. 
Table A5: Instrumental Variable Model (without Selectivity Correction) for Mortgage Characteristics of Young Households (18-44)

\begin{tabular}{|c|c|c|c|c|c|c|}
\hline & \multicolumn{2}{|c|}{$\begin{array}{l}(1) \\
\text { Refinanced within } \\
\text { past } 3 \text { years }\end{array}$} & \multicolumn{2}{|c|}{$\begin{array}{l}(2) \\
\text { Alternative Mortgage } \\
\text { Product }\end{array}$} & \multicolumn{2}{|c|}{$\begin{array}{c}(3) \\
\text { Adjustable Rate } \\
\text { Mortgage }\end{array}$} \\
\hline & $\beta / \mathrm{SE}$ & Margin & $\beta / \mathrm{SE}$ & Margin & $\beta / \mathrm{SE}$ & Margin \\
\hline \multicolumn{7}{|l|}{ Financial Literacy } \\
\hline Financial literacy score $(0-4)$ & $\begin{array}{r}-0.096 \\
(0.180)\end{array}$ & -0.019 & $\begin{array}{r}-0.380^{*} \\
(0.237)\end{array}$ & $-0.078^{*}$ & $\begin{array}{l}0.573^{* * *} \\
(0.109)\end{array}$ & $0.030^{* * *}$ \\
\hline \multicolumn{7}{|l|}{ Behavioural Characteristics } \\
\hline Patience $(0-10)$ & $\begin{array}{c}0.018 \\
(0.036)\end{array}$ & 0.007 & $\begin{array}{r}-0.024 \\
(0.046)\end{array}$ & -0.005 & $\begin{array}{r}-0.030 \\
(0.034)\end{array}$ & -0.030 \\
\hline Present biased $(=1)$ & $\begin{array}{r}-0.164 \\
(0.233)\end{array}$ & -0.053 & $\begin{array}{l}0.912^{* * *} \\
(0.247)\end{array}$ & $0.176^{* * *}$ & $\begin{array}{r}-0.043 \\
(0.210)\end{array}$ & 0.000 \\
\hline Risk attitude $(0-10)$ & $\begin{array}{l}0.106^{* * *} \\
(0.040)\end{array}$ & $0.034^{* * *}$ & $\begin{array}{c}0.002 \\
(0.049)\end{array}$ & -0.000 & $\begin{array}{r}-0.008 \\
(0.036)\end{array}$ & -0.019 \\
\hline \multicolumn{7}{|l|}{ Demographics } \\
\hline Male (= 1) & $\begin{array}{r}-0.219 \\
(0.207)\end{array}$ & -0.077 & $\begin{array}{c}0.025 \\
(0.267)\end{array}$ & 0.008 & $\begin{array}{r}-0.067 \\
(0.186)\end{array}$ & 0.113 \\
\hline Education leaving age (years) & $\begin{array}{l}0.084^{* *} \\
(0.036)\end{array}$ & $0.026^{* *}$ & $\begin{array}{c}-0.030 \\
(0.044)\end{array}$ & -0.006 & $\begin{array}{r}-0.055^{*} \\
(0.031)\end{array}$ & $-0.014^{*}$ \\
\hline \multicolumn{7}{|l|}{ Household Finances } \\
\hline Household income $(£ 10,000 \mathrm{~s})$ & $\begin{array}{c}0.054 \\
(0.104)\end{array}$ & 0.016 & $\begin{array}{r}-0.030 \\
(0.120)\end{array}$ & -0.005 & $\begin{array}{r}-0.064 \\
(0.090)\end{array}$ & -0.001 \\
\hline Household income ${ }^{2}$ & $\begin{array}{r}-0.005 \\
(0.006)\end{array}$ & -0.001 & $\begin{array}{c}0.004 \\
(0.006)\end{array}$ & 0.001 & $\begin{array}{c}0.004 \\
(0.005)\end{array}$ & 0.000 \\
\hline \multicolumn{7}{|l|}{ Financial Circumstances } \\
\hline Recent income loss $(=1)$ & $\begin{array}{r}-0.163 \\
(0.269)\end{array}$ & -0.051 & $\begin{array}{c}0.641^{* *} \\
(0.290)\end{array}$ & $0.123^{* *}$ & $\begin{array}{l}0.761^{* * *} \\
(0.253)\end{array}$ & $0.304^{* * *}$ \\
\hline Credit constrained $(=1)$ & $\begin{array}{c}0.658^{*} \\
(0.379)\end{array}$ & $0.205^{*}$ & $\begin{array}{c}0.402 \\
(0.411)\end{array}$ & 0.078 & $\begin{array}{c}0.554 \\
(0.394)\end{array}$ & 0.277 \\
\hline Observations & 308 & & 308 & & 308 & \\
\hline F-statistic of first stage & 12.260 & & 14.690 & & 12.360 & \\
\hline LR chi2 & 28.589 & & 35.145 & & 94.862 & \\
\hline Prob > chi 2 & 0.007 & & 0.001 & & 0.000 & \\
\hline Wald test of exogeneity & 0.849 & & 0.925 & & 0.002 & \\
\hline Baseline predicted probability & 0.301 & & 0.165 & & 0.485 & \\
\hline
\end{tabular}

Note: Table shows results from instrumental variable probit models (the equivalent model with selectivity correction is shown in Table 8). ${ }^{*} \mathrm{p}<0.1,{ }^{* *} \mathrm{p}<0.05,{ }^{* * *} \mathrm{p}<0.01$. Average marginal effects reported, standard errors in parentheses. Financial literacy is instrumented by the math level in school. The dependent variables are $1 / 0$ dummy variables for, respectively: Column 1 , whether the individual refinanced the mortgage within the last 3 years $(=1)$; Column 2, whether the individual holds an alternative mortgage product $(=1)$ or a standard repayment mortgage; Column 3 , whether the individual holds an adjustable rate mortgage $(=0)$ or a fixed rate mortgage. Sample includes only young households. Additional controls not shown: 1/0 dummies for marital status, dependent children and (spouse) employment status. 
Table A6: Instrumental Variable Model with Selectivity Correction for Mortgage Borrowing of Young Households (18-44) excluding "Don't knows"

\begin{tabular}{|c|c|c|c|c|}
\hline \multirow[b]{2}{*}{ Inverse Mills Ratio } & \multicolumn{2}{|c|}{$\begin{array}{c}(1) \\
\text { Loan-to-Value } \\
\text { Ratio }\end{array}$} & \multicolumn{2}{|c|}{$\begin{array}{c}\text { Loan-to-Income } \\
\text { Ratio }\end{array}$} \\
\hline & $\begin{array}{c}-4.713^{* * *} \\
(1.202)\end{array}$ & $-0.250^{* * *}$ & $\begin{array}{c}-18.384^{* * *} \\
(6.542)\end{array}$ & $-0.227^{* * *}$ \\
\hline \multicolumn{5}{|l|}{ Financial Literacy } \\
\hline Financial literacy score $(0-4)$ & $\begin{array}{c}-0.901^{* * *} \\
(0.320)\end{array}$ & $-0.014^{* * *}$ & $\begin{array}{c}-2.378^{* *} \\
(0.945)\end{array}$ & $-0.062^{* *}$ \\
\hline \multicolumn{5}{|l|}{ Behavioural Characteristics } \\
\hline Patience $(0-10)$ & $\begin{array}{c}0.087^{* *} \\
(0.040)\end{array}$ & $0.001^{* *}$ & $\begin{array}{c}-0.056^{* *} \\
(0.024)\end{array}$ & $-0.009^{* *}$ \\
\hline Present biased $(=1)$ & $\begin{array}{c}0.264 \\
(0.173)\end{array}$ & 0.010 & $\begin{array}{c}0.068 \\
(0.185)\end{array}$ & 0.036 \\
\hline Risk attitude $(0-10)$ & $\begin{array}{c}0.039 \\
(0.058)\end{array}$ & -0.015 & $\begin{array}{c}-0.065 \\
(0.069)\end{array}$ & -0.025 \\
\hline \multicolumn{5}{|l|}{ Demographics } \\
\hline Male $(=1)$ & $\begin{array}{l}0.612^{* * *} \\
(0.189)\end{array}$ & $0.021^{* * *}$ & $\begin{array}{c}0.098 \\
(0.198)\end{array}$ & -0.044 \\
\hline Education leaving age (years) & $\begin{array}{l}0.283^{* * *} \\
(0.096)\end{array}$ & $0.017^{* * *}$ & $\begin{array}{c}0.080 \\
(0.085)\end{array}$ & -0.006 \\
\hline \multicolumn{5}{|l|}{ Financial Circumstances } \\
\hline Recent income loss $(=1)$ & $\begin{array}{r}-0.254 \\
(0.177)\end{array}$ & -0.027 & $\begin{array}{r}-0.150 \\
(0.192)\end{array}$ & 0.023 \\
\hline Credit constrained $(=1)$ & $\begin{array}{r}-0.006 \\
(0.205)\end{array}$ & -0.012 & $\begin{array}{c}0.043 \\
(0.276)\end{array}$ & -0.056 \\
\hline Observations & 490 & & 490 & \\
\hline F-statistic of first stage & 29.220 & & 29.220 & \\
\hline LR chi2 & 143.854 & & 255.828 & \\
\hline Prob > chi2 & 0.000 & & 0.000 & \\
\hline Wald test of exogeneity & 0.115 & & 0.313 & \\
\hline Baseline predicted probability & 0.192 & & 0.141 & \\
\hline
\end{tabular}

Note: Table shows results from instrumental variable probit models with selectivity correction. This table corresponds to Table 7, but here the sample excludes all respondents who answered "don't know" to the very first literacy question and/or those who answered "don't know" to three or more questions. ${ }^{*} \mathrm{p}<0.1,{ }^{* *} \mathrm{p}<0.05$, ${ }^{* * *} \mathrm{p}<0.01$. Average marginal effects reported, standard errors in parentheses. Financial literacy instrumented by the math level in school. The selection model is whether the individual holds a mortgage or not, instrumented by the local house price to income ratio (the selection correction term is shown by the inverse mills ratio). The dependent variable in Column 1 is a 1/0 dummy variable indicating whether the loan-to-value ratio of the household is larger than the 75 th percentile in the distribution. Likewise, the dependent variable in Column 2 is a $1 / 0$ dummy variable indicating whether the loan-to-income ratio of the household is larger than the 75 th percentile in the distribution. Sample includes only young households. Additional controls not shown: 1/0 dummies for marital status, dependent children and (spouse) employment status. 
Table A7: Instrumental Variable Model with Selectivity Correction for Mortgage Characteristics of Young Households (18-44) excluding "Don't knows"

(3)

(4)

(5)

Refinanced within Alternative Mortgage Adjustable Rate past 3 years Product Mortgage

\begin{tabular}{|c|c|c|c|c|c|c|}
\hline Inverse Mills Ratio & $\begin{array}{c}-20.482^{* * *} \\
(2.920)\end{array}$ & $-1.108^{* * *}$ & $\begin{array}{c}-6.117^{* * *} \\
(1.765)\end{array}$ & $-0.384^{* * *}$ & $\begin{array}{c}-20.940^{* * *} \\
(2.252)\end{array}$ & $-0.017^{* * *}$ \\
\hline \multicolumn{7}{|l|}{ Financial Literacy } \\
\hline Financial literacy score $(0-4)$ & $\begin{array}{c}-2.719^{* * *} \\
(0.340)\end{array}$ & $-0.123^{* * *}$ & $\begin{array}{c}-1.150^{* *} \\
(0.502)\end{array}$ & $-0.053^{* *}$ & $\begin{array}{l}2.750^{* * *} \\
(0.331)\end{array}$ & $0.021^{* * *}$ \\
\hline \multicolumn{7}{|l|}{ Behavioural Characteristics } \\
\hline Patience $(0-10)$ & $\begin{array}{l}0.038^{* *} \\
(0.019)\end{array}$ & $-0.003^{* *}$ & $\begin{array}{l}0.122^{* *} \\
(0.057)\end{array}$ & $0.007^{* *}$ & $\begin{array}{c}-0.056 \\
(0.049)\end{array}$ & -0.024 \\
\hline Present biased $(=1)$ & $\begin{array}{c}-0.009 \\
(0.176)\end{array}$ & -0.062 & $\begin{array}{l}0.899^{* *} \\
(0.406)\end{array}$ & $0.100^{* *}$ & $\begin{array}{r}-0.017 \\
(0.138)\end{array}$ & 0.014 \\
\hline Risk attitude $(0-10)$ & $\begin{array}{c}0.028 \\
(0.032)\end{array}$ & 0.014 & $\begin{array}{c}0.094 \\
(0.065)\end{array}$ & 0.004 & $\begin{array}{c}-0.030 \\
(0.036)\end{array}$ & -0.016 \\
\hline \multicolumn{7}{|l|}{ Demographics } \\
\hline Male $(=1)$ & $\begin{array}{r}-0.221 \\
(0.184)\end{array}$ & -0.092 & $\begin{array}{c}0.586 \\
(0.395)\end{array}$ & 0.018 & $\begin{array}{c}0.199 \\
(0.133)\end{array}$ & 0.049 \\
\hline Education leaving age (years) & $\begin{array}{c}-0.084 \\
(0.058)\end{array}$ & -0.018 & $\begin{array}{c}0.202 \\
(0.232)\end{array}$ & 0.001 & $\begin{array}{c}0.085 \\
(0.059)\end{array}$ & 0.018 \\
\hline \multicolumn{7}{|l|}{ Household Finances } \\
\hline Household income $(£ 10,000$ s) & $\begin{array}{r}-0.018 \\
(0.090)\end{array}$ & 0.036 & $\begin{array}{c}0.099 \\
(0.085)\end{array}$ & 0.009 & $\begin{array}{c}0.062 \\
(0.070)\end{array}$ & 0.033 \\
\hline Household income $^{2}$ & $\begin{array}{r}-0.002 \\
(0.004)\end{array}$ & -0.001 & $\begin{array}{r}-0.001 \\
(0.005)\end{array}$ & 0.000 & $\begin{array}{c}0.001 \\
(0.003)\end{array}$ & -0.001 \\
\hline \multicolumn{7}{|l|}{ Financial Circumstances } \\
\hline Recent income loss $(=1)$ & $\begin{array}{c}0.156 \\
(0.145)\end{array}$ & -0.025 & $\begin{array}{c}0.253 \\
(0.466)\end{array}$ & 0.056 & $\begin{array}{c}-0.085 \\
(0.279)\end{array}$ & 0.122 \\
\hline Credit constrained $(=1)$ & $\begin{array}{r}-0.173 \\
(0.170)\end{array}$ & 0.016 & $\begin{array}{c}-0.075 \\
(0.302)\end{array}$ & -0.016 & $\begin{array}{c}0.178 \\
(0.170)\end{array}$ & -0.003 \\
\hline Observations & 490 & & 490 & & 490 & \\
\hline F-statistic of first stage & 25.240 & & 25.240 & & 25.240 & \\
\hline LR chi2 & 484.811 & & 106.693 & & 782.203 & \\
\hline Prob > chi2 & 0.000 & & 0.000 & & 0.000 & \\
\hline Wald test of exogeneity & 0.329 & & 0.498 & & 0.408 & \\
\hline Baseline predicted probability & 0.128 & & 0.081 & & 0.238 & \\
\hline
\end{tabular}

Note: Table shows results from instrumental variable probit models with selectivity correction. This table corresponds to Table 8, but here the sample excludes all respondents who answered "don't know" to the very first literacy question and/or those who answered "don't know" to three or more questions. ${ }^{*} \mathrm{p}<0.1,{ }^{* *} \mathrm{p}<0.05$, ${ }^{* * *}$ $p<0.01$. Average marginal effects reported, standard errors in parentheses. Financial literacy instrumented by the math level in school. The selection model is whether the individual holds a mortgage or not, instrumented by the local house price to income ratio (the selection correction term is shown by the inverse mills ratio). The dependent variables are 1/0 dummy variables for, respectively: Column 1, whether the individual refinanced the mortgage within the last 3 years $(=1)$; Column 2, whether the individual holds an alternative mortgage product $(=1)$ or a standard repayment mortgage; Column 3, whether the individual holds an adjustable rate mortgage $(=0)$ or a fixed rate mortgage. Sample includes only young households. Additional controls not shown: 1/0 dummies for marital status, dependent children and (spouse) employment status. 